\title{
Dissolved inorganic carbon dynamics and air-sea carbon dioxide fluxes during coccolithophore blooms in the northwest European continental margin (northern Bay of Biscay)
}

\author{
K. Suykens, ${ }^{1}$ B. Delille, ${ }^{1}$ L. Chou, ${ }^{2}$ C. De Bodt, ${ }^{2}$ J. Harlay, ${ }^{1,2}$ and A. V. Borges ${ }^{1}$ \\ Received 18 November 2009; revised 8 April 2010; accepted 11 May 2010; published 17 September 2010.
}

[1] We report a data set of dissolved inorganic carbon (DIC) obtained during three cruises in the northern Bay of Biscay carried out in June 2006, May 2007, and May 2008. During these cruises, blooms of the coccolithophore Emiliania huxleyi occurred, as indicated by patches of high reflectance on remote sensing images, phytoplankton pigment signatures, and microscopic examinations. Total alkalinity showed a nonconservative behavior as a function of salinity due to the cumulative effect of net community calcification (NCC) on seawater carbonate chemistry during bloom development. The cumulative effect of NCC and net community production (NCP) on DIC and the partial pressure of $\mathrm{CO}_{2}\left(\mathrm{pCO}_{2}\right)$ were evaluated. The decrease of DIC (and increase of $\left.\mathrm{pCO}_{2}\right)$ due to NCC was overwhelmingly lower than the decrease of DIC (and decrease of $\mathrm{pCO}_{2}$ ) due to NCP $(\mathrm{NCC}: \mathrm{NCP} \ll 1)$. During the cruises, the northern Bay of Biscay acted as a sink of atmospheric $\mathrm{CO}_{2}$ (on average $\sim-9.7 \mathrm{mmol} \mathrm{C} \mathrm{m}^{-2} \mathrm{~d}^{-1}$ for the three cruises). The overall effect of $\mathrm{NCC}$ in decreasing the $\mathrm{CO}_{2}$ sink during the cruises was low (on average $\sim 12 \%$ of total air-sea $\mathrm{CO}_{2}$ flux). If this is a general feature in naturally occurring phytoplankton blooms in the North Atlantic Ocean (where blooms of coccolithophores are the most intense and recurrent), and in the global ocean, then the potential feedback on increasing atmospheric $\mathrm{CO}_{2}$ of the projected decrease of pelagic calcification due to thermodynamic $\mathrm{CO}_{2}$ "production" from calcification is probably minor compared to potential feedbacks related to changes of NCP.

Citation: Suykens, K., B. Delille, L. Chou, C. De Bodt, J. Harlay, and A. V. Borges (2010), Dissolved inorganic carbon dynamics and air-sea carbon dioxide fluxes during coccolithophore blooms in the northwest European continental margin (northern Bay of Biscay), Global Biogeochem. Cycles, 24, GB3022, doi:10.1029/2009GB003730.

\section{Introduction}

[2] Balch et al. [2007] evaluated from remote sensing data the contemporary global calcification related to coccolithophores to $1.6 \pm 0.3 \mathrm{Pg} \mathrm{PIC} \mathrm{yr}^{-1}\left(1 \mathrm{Pg}=10^{15} \mathrm{~g}\right.$; PIC, particulate inorganic carbon). Other estimates of contemporary global pelagic calcification range between $0.7 \mathrm{Pg}$ PIC $\mathrm{yr}^{-1}$, based on accumulation rates and sediment trap data [Milliman et al., 1999], and 1.4 Pg PIC $\mathrm{yr}^{-1}$, based on the seasonal cycle of total alkalinity (TA) in the euphotic zone [Lee, 2001]. Each of these estimates of global pelagic calcification suffers from specific shortcomings. For instance, the estimate of Milliman et al. [1999] might be underestimated due to supralysoclinal dissolution of calcium carbonate $\left(\mathrm{CaCO}_{3}\right)$ [e.g., Wollast and Chou, 1998; Beaufort et al., 2007; Berelson et al., 2007],

\footnotetext{
${ }^{1}$ Unité d'Océanographie Chimique, Université de Liège, Liège, Belgium.

${ }^{2}$ Laboratoire d'Océanographie Chimique et Géochimie des Eaux, Université Libre de Bruxelles, Brussels, Belgium.

Copyright 2010 by the American Geophysical Union. 0886-6236/10/2009GB003730
}

and the TA analysis of Lee [2001] could be affected by other processes than calcification such as nutrient uptake and release or mixing of water masses. The estimate of Balch et al. [2007] is probably less biased by the sparseness of data coverage compared to the two other approaches, although strongly dependent on the predictive capability of the algorithm used to process the remote sensing data. Threedimensional circulation models mostly tuned to reproduce the observed TA distributions also provide a wide range of global pelagic calcification values from 0.6 to $1.8 \mathrm{Pg}$ PIC $\mathrm{yr}^{-1}$ [Bacastow and Maier-Reimer, 1990; Yamanaka and Tajika, 1996; Archer et al., 1998; Murnane et al., 1999; Heinze et al., 2003; Moore et al., 2004; Jin et al., 2006; Gehlen et al., 2007; Hofmann and Schellnhuber, 2009]. The fact that the estimate of Balch et al. [2007] of contemporary global pelagic calcification related to coccolithophores is comparable to the other estimates would imply that coccolithophores are the most important pelagic calcifiers in the oceans.

[3] The development of coccolithophore blooms affects the seawater carbonate chemistry, and air-sea $\mathrm{CO}_{2}$ fluxes, through the organic carbon pump and the carbonate counterpump. The organic carbon pump relies on organic carbon 


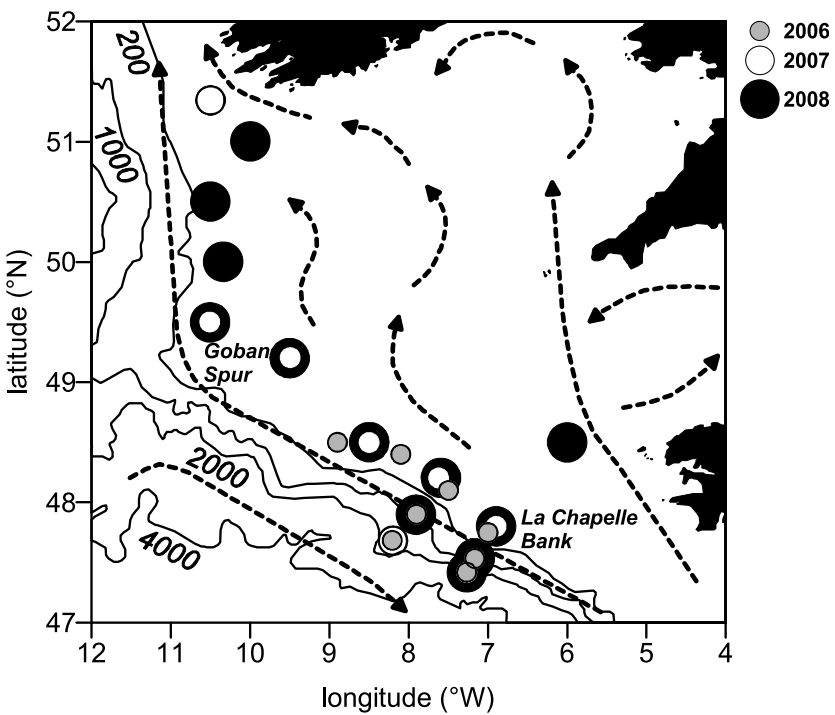

Figure 1. Map of the study site showing the sampling stations in June 2006 (grey circles), May 2007 (open circles), and May 2008 (black circles), the $200 \mathrm{~m}, 1000 \mathrm{~m}, 2000$ $\mathrm{m}$, and $4000 \mathrm{~m}$ isobaths (solid lines), and the general residual circulation (dotted arrows) based on Pingree and Le Cann [1989], Pingree [1993], Pingree et al. [1999], and Huthnance et al. [2001].

production by photosynthesis and leads to an uptake of $\mathrm{CO}_{2}$ from surface waters, according to:

$$
\mathrm{CO}_{2}+\mathrm{H}_{2} \mathrm{O} \rightarrow \mathrm{CH}_{2} \mathrm{O}+\mathrm{O}_{2}
$$

[4] The carbonate counterpump relies on the production of $\mathrm{CaCO}_{3}$, leading to a thermodynamic shift of $\mathrm{HCO}_{3}^{-}$to $\mathrm{CO}_{2}$, hence, a release of $\mathrm{CO}_{2}$ to surrounding surface waters, according to:

$$
\mathrm{Ca}^{2+}+2 \mathrm{HCO}_{3}^{-} \rightarrow \mathrm{CaCO}_{3}+\mathrm{CO}_{2}+\mathrm{H}_{2} \mathrm{O}
$$

[5] The ratio between calcification (carbonate counterpump), and organic carbon production (organic carbon pump), the C:P ratio, depends on the life cycle (bloom development) and growth conditions of coccolithophores [Fernández et al., 1993; Paasche and Brubak, 1994; Paasche, 2002; Delille et al., 2005]. At the onset of the coccolithophore bloom, when nutrients are available for growth, organic carbon production dominates over calcification $(\mathrm{C}: \mathrm{P} \ll 1$, the so-called organic phase). At the end of the bloom, in nutrientdepleted conditions and high irradiances (due to stronger stratification), organic carbon production decreases and calcification increases $(\mathrm{C}: \mathrm{P} \leq 1$, the so-called inorganic phase).

[6] The accumulation of anthropogenic $\mathrm{CO}_{2}$ in the oceans [e.g., Sabine et al., 2004] has altered carbonate chemistry in surface waters (ocean acidification) since preindustrial times, and is expected to continue to do so in the coming centuries [e.g., Caldeira and Wickett, 2003; Orr et al., 2005; Cao et al., 2007; McNeil and Matear, 2007]. Changes of the carbonate chemistry of surface waters related to ocean acidification can alter the rates and fates of primary production and calcification of numerous marine organisms and communities [as reviewed by Raven et al., 2005; Kleypas et al., 2006; Fabry et al., 2008; Doney et al., 2009]. Such changes can provide either positive or negative feedbacks on increasing atmospheric $\mathrm{CO}_{2}$ by modifying the flux of $\mathrm{CO}_{2}$ between the ocean and the atmosphere.

[7] Several manipulative experiments to test the effect of ocean acidification on coccolithophores have shown that while calcification would decrease, the export of organic carbon would increase mainly through increasing production of transparent exopolymer particles (TEP) [Riebesell et al., 2000; Engel et al., 2004a, 2004b; Delille et al., 2005; Riebesell et al., 2007]. On the other hand, the reduction of pelagic calcification due to ocean acidification could also lead to a reduction of carbon export due to the decrease of the ballast effect of $\mathrm{CaCO}_{3}$ on marine particles [e.g., Armstrong et al., 2002; Klaas and Archer, 2002; Barker et al., 2003; Hofmann and Schellnhuber, 2009]. The modelling study of Hofmann and Schellnhuber [2009] suggested that the positive feedback on increasing atmospheric $\mathrm{CO}_{2}$ related to the decrease of carbon export from the reduction of ballast effect of $\mathrm{CaCO}_{3}$ on marine particles would represent $\sim 40 \%$ of the negative feedback related to the decrease of the $\mathrm{CO}_{2}$ emission to the atmosphere due to the reduction of pelagic calcification. For a credible implementation in mathematical models of such feedback mechanisms to allow the projection of a future evolution of marine carbon biogeochemistry under global change, it is required to understand present day biogeochemistry and ecology of naturally occurring pelagic calcifying communities. In particular, the overall effect of phytoplankton communities on the $\mathrm{C}: \mathrm{P}$ ratio, carbonate chemistry, and air-sea $\mathrm{CO}_{2}$ fluxes.

[8] In the northwest European continental margin, blooms of the coccolithophore Emiliania huxleyi have been frequently reported [Holligan et al., 1983; Garcia-Soto et al., 1995; Wollast and Chou, 1998, 2001; Godoi et al., 2009; Harlay et al., 2009, 2010]. Here, we report a data set of carbonate chemistry in surface waters obtained during three cruises in the northern Bay of Biscay (Figure 1). We evaluate the relative effect of calcification and organic carbon production on seawater carbonate chemistry and air-sea $\mathrm{CO}_{2}$ fluxes.

\section{Material and Methods}

\subsection{Cruises and Sampling}

[9] Three cruises were carried out in the northern Bay of Biscay from 31 May to 9 June 2006 (BG06/11 cruise), 10 May to 24 May 2007 (BG07/12 cruise), and 7 May to 23 May 2008 (BG08/12 cruise). Sampling of pH, TA, oxygen $\left(\mathrm{O}_{2}\right)$, and phosphate $\left(\mathrm{PO}_{4}^{3-}\right)$ was carried out with a rosette of 12 Niskin bottles (12 L) coupled to a conductivitytemperature-depth probe (Seabird SBE21). Depths of sampling covered surface waters, thermocline, and bottom waters down to the seafloor over the continental shelf and down to maximum $1400 \mathrm{~m}$ over the continental slope. Because of shorter ship-time, sampling during the June 2006 cruise was limited to the area around the La Chapelle 
Bank, while during the other two cruises sampling was also carried out further north along the continental shelf break (Figure 1).

\subsection{Analytical Methods}

[10] Underway measurements of the partial pressure of $\mathrm{CO}_{2}\left(\mathrm{pCO}_{2}\right)$ were carried out in surface waters $(2 \mathrm{~m} \mathrm{depth})$ using an equilibrator [Frankignoulle et al., 2001], and a nondispersive infrared $\mathrm{CO}_{2}$ analyzer (Li-Cor 6262) calibrated with pure nitrogen (Air Liquide Belgium) and two gas mixtures with a $\mathrm{CO}_{2}$ molar fraction of 366 and $810 \mathrm{ppm}$ (Air Liquide Belgium), that were calibrated against standards with a $\mathrm{CO}_{2}$ molar fraction of 361 and $774 \mathrm{ppm}$ acquired from National Oceanic and Atmospheric Administration (NOAA, Global Monitoring Division, Carbon Cycle Greenhouse Gases Group). Temperature at the outlet of the equilibrator was measured with a Metrohm Pt-100 temperature sensor. The correction of $\mathrm{pCO}_{2}$ for the difference between equilibrator and in situ temperature was carried out with the algorithm given by Takahashi et al. [1993]. Sea surface temperature (SST) and salinity were measured underway ( $2 \mathrm{~m}$ depth) with a Seabird thermosalinograph (SBE 21).

[11] Measurements of $\mathrm{pH}$ were carried out with a combined electrode (Metrohm 6.0232.100), calibrated on the total hydrogen ion concentration scale, using TRIS (2-amino2-hydroxymethyl-1,3-propanediol) and AMP (2-aminopyridine) buffers prepared at a salinity of 35 according to Dickson [1993]. Measurements of TA were carried out by open-cell titration with $\mathrm{HCl} 0.1 \mathrm{M}$ according to Gran [1952] on $100 \mathrm{~mL}$ filtered (GF/F Whatman) seawater samples, and data were quality checked with certified reference material acquired from Andrew Dickson (Scripps Institution of Oceanography, University of California, San Diego). Dissolved inorganic carbon (DIC) and the saturation state of calcite $\left(\Omega_{\mathrm{CAL}}\right)$ were computed from $\mathrm{pH}$ and TA using the carbonic acid dissociation constants of Mehrbach et al. [1973] refitted by Dickson and Millero [1987], and the calcite solubility of Mucci [1983].

[12] Concentrations of dissolved $\mathrm{O}_{2}$ were measured by Winkler titration with a potentiometric end point determination. Reagents and standardizations were similar to those described by Knap et al. [1996]. The $\mathrm{O}_{2}$ saturation level (\% $\mathrm{O}_{2}$ ) was calculated from the measured $\mathrm{O}_{2}$ concentration and the $\mathrm{O}_{2}$ concentration at saturation computed with the algorithm given by Benson and Krause [1984]. $\mathrm{PO}_{4}^{3-}$ was measured colorimetrically with the molybdate and ascorbic acid method described by Grasshoff et al. [1983].

\subsection{Evaluation of the Effect of Biological Activity on Carbonate Chemistry of Surface Waters and Air-Sea $\mathrm{CO}_{2}$ Fluxes}

[13] The effect on DIC, $\mathrm{pCO}_{2}$, and $\Omega_{\mathrm{CAL}}$ in surface waters of net community production (NCP) and net community calcification (NCC) was estimated on the basis of the changes between the surface layer and the deep layer of nutrients and of TA, respectively. Changes in nutrients and TA were computed as the difference of the average concentration in the surface layer (top $20 \mathrm{~m},\langle\mathrm{X}\rangle_{0-20 \mathrm{~m}}$ ) and the average concentration of the deep layer ( $80 \mathrm{~m}$ to seafloor, $\left.\langle\mathrm{X}\rangle_{80 \mathrm{~m} \text {-bottom }}\right)$. The lower limit of the surface layer $(20 \mathrm{~m})$ was chosen to include data within the euphotic layer (euphotic depth typically of $\sim 30 \mathrm{~m}$ during the cruises, not shown), while the upper limit of the deep layer $(80 \mathrm{~m})$ was chosen to avoid the base of the thermocline (at some stations down to $70 \mathrm{~m}$, not shown). For the deeper stations on the continental slope, the averaging of the deep layer data was made down to $150 \mathrm{~m}$.

[14] TA and DIC were normalized to a constant salinity of $35.5\left(\mathrm{TA}_{35.5}\right.$ and $\mathrm{DIC}_{35.5}$, respectively) according to:

$$
\begin{aligned}
T A_{35.5} & =35.5 \frac{\mathrm{TA}}{\mathrm{S}} \\
D I C_{35.5} & =35.5 \frac{\mathrm{DIC}}{\mathrm{S}}
\end{aligned}
$$

where $T A$ and $D I C$ are the observed values at the observed salinity $(S)$.

[15] Hereafter, $\mathrm{pCO}_{2} @ \mathrm{SST}$ refers to $\mathrm{pCO}_{2}$ at SST and $\mathrm{pCO}_{2} @ 13^{\circ} \mathrm{C}$ refers to the $\mathrm{pCO}_{2}$ normalized to a temperature of $13^{\circ} \mathrm{C}$ applying the algorithm of Takahashi et al. [1993]. The change of $\mathrm{pCO}_{2}$ due to temperature $(T)$ changes $\left(\triangle \mathrm{pCO}_{2 \mathrm{SST}}\right)$ was computed with the algorithm of Takahashi et al. [1993] and the change of $T(\Delta T)$ :

$$
\Delta T=\langle T\rangle_{0-20 \mathrm{~m}}-\langle T\rangle_{80 \mathrm{~m}-\text { bottom }}
$$

[16] For the anomaly of $T A$ ( $\left.T A_{\text {anomaly }}\right)$ to only represent $\mathrm{CaCO}_{3}$ production and dissolution and to exclude the effect of organic matter production and degradation, TA values have to be corrected for $\mathrm{PO}_{4}^{3-}$ and nitrate $\left(\mathrm{NO}_{3}^{-}\right)$assimilation and release [Brewer and Goldman, 1976]. $\mathrm{PO}_{4}^{3-}$ assimilation is given by the term $\left\langle\mathrm{PO}_{4}^{3-}\right\rangle_{80 \mathrm{~m}-\text { bottom }}-\left\langle\mathrm{PO}_{4}^{3-}\right\rangle_{0-20 \mathrm{~m}}$. In absence of $\mathrm{NO}_{3}^{-}$data during the June 2006 cruise, $\mathrm{NO}_{3}^{-}$ assimilation was computed for the three cruises from $\mathrm{PO}_{4}^{3-}$ assimilation, using the Redfield ratio (16:1). During the May 2007 and May 2008 cruises, the measured $\mathrm{NO}_{3}^{-}: \mathrm{PO}_{4}^{3-}$ ratios were 16.7 and 15.7, respectively (not shown), hence close to the Redfield ratio. The $\mathrm{TA}_{\text {anomaly }}$ was computed according to:

$$
\begin{aligned}
T A_{\text {anomaly }}= & \left\langle T A_{35.5}\right\rangle_{0-20 \mathrm{~m}}-16 \times\left(\left\langle\mathrm{PO}_{4}^{3-}\right\rangle_{80 \mathrm{~m}-\text { bottom }}-\left\langle\mathrm{PO}_{4}^{3-}\right\rangle_{0-20 \mathrm{~m}}\right) \\
& -\left(\left\langle\mathrm{PO}_{4}^{3-}\right\rangle_{80 \mathrm{~m}-\text { bottom }}-\left\langle\mathrm{PO}_{4}^{3-}\right\rangle_{0-20 \mathrm{~m}}\right)-\left\langle T A_{35.5}\right\rangle_{80 \mathrm{~m}-\text { bottom }}
\end{aligned}
$$

[17] The change of DIC in surface waters due to net organic carbon production $\left(\triangle D I C_{\text {org }}\right)$ was computed from the change of $\mathrm{PO}_{4}^{3-}$ converted to carbon using the Redfield ratio (106:1), according to:

$$
\Delta D I C_{\text {org }}=106 \times\left(\left\langle\mathrm{PO}_{4}^{3-}\right\rangle_{0-20 \mathrm{~m}}-\left\langle\mathrm{PO}_{4}^{3-}\right\rangle_{80 \mathrm{~m}-\text { bottom }}\right)
$$

[18] The change of DIC in surface waters due to net $\mathrm{CaCO}_{3}$ production $\left(\triangle D I C_{\text {inorg }}\right)$ was computed using the TA anomaly technique [e.g., Smith and Key, 1975] according to:

$$
\Delta D I C_{\text {inorg }}=0.5 \times T A_{\text {anomaly }}
$$

[19] To estimate the change of $\mathrm{pCO}_{2}$ due to $\Delta D I C_{\text {org }}$ and $\Delta D I C_{\text {inorg }}\left(\triangle \mathrm{pCO}_{2 \text { org }}\right.$ and $\Delta \mathrm{pCO}_{2 \text { inorg }}$, respectively), we first computed $D I C$ at atmospheric $\mathrm{CO}_{2}$ equilibrium $\left(D I C_{\text {eq }}\right)$ 
from an average $T A$ of $2340 \mu \mathrm{mol} \mathrm{kg}{ }^{-1}$, a $\mathrm{pCO}_{2}$ of $380 \mathrm{ppm}$, an average temperature of $13^{\circ} \mathrm{C}$, and an average salinity of 35.5.

[20] The value $\Delta \mathrm{pCO}_{2 \text { org }}$ was computed as the difference between atmospheric equilibrium (380 ppm) and $\mathrm{pCO}_{2}$ computed from $\mathrm{DIC}_{\mathrm{org}}$, a TA of $2340 \mu \mathrm{mol} \mathrm{kg}{ }^{-1}$, a temperature of $13^{\circ} \mathrm{C}$ and a salinity of 35.5 , where $\mathrm{DIC}_{\text {org }}$ is given by:

$$
D I C_{\mathrm{org}}=D I C_{\mathrm{eq}}+\Delta D I C_{\mathrm{org}}
$$

$\triangle \mathrm{pCO}_{2 \text { inorg }}$ was computed as the difference between atmospheric equilibrium (380 ppm) and $\mathrm{pCO}_{2}$ computed from $D I C_{\text {inorg }}, T A_{\text {inorg, }}$, a temperature of $13^{\circ} \mathrm{C}$, and a salinity of 35.5 , where $D I C_{\text {inorg }}$ and $T A_{\text {inorg }}$ are given by:

$$
\begin{gathered}
D I C_{\text {inorg }}=D I C_{\text {eq }}+\Delta D I C_{\text {inorg }} \\
T A_{\text {inorg }}=2340+\mathrm{TA}_{\text {anomaly }}
\end{gathered}
$$

[21] The change of $\Omega_{\mathrm{CAL}}$ due to net organic carbon production $\left(\Delta \Omega_{\text {CALorg }}\right)$ was calculated as the difference between $\Omega_{\text {CALeq }}$ and $\Omega_{\text {CALorg, where }} \Omega_{\text {CALeq }}$ was computed from $D I C_{\mathrm{eq}}$, a $T A$ of $2340 \mu \mathrm{mol} \mathrm{kg}{ }^{-1}$, a temperature of $13^{\circ} \mathrm{C}$, and a salinity of 35.5 , and $\Omega_{\text {CALorg }}$ was computed from $D I C_{\text {org }}$, a $T A$ of $2340 \mu \mathrm{mol} \mathrm{kg}^{-1}$, a temperature of $13^{\circ} \mathrm{C}$ and a salinity of 35.5. The change of $\Omega_{\mathrm{CAL}}$ due to net $\mathrm{CaCO}_{3}$ production $\left(\Delta \Omega_{\text {CALinorg }}\right)$ was calculated as the difference between $\Omega_{\text {CALeq }}$ and $\Omega_{\text {CALinorg, }}$ where $\Omega_{\text {CALinorg }}$ was computed from $D I C_{\text {inorg }}, T A_{\text {inorg }}$, a temperature of $13^{\circ} \mathrm{C}$, and a salinity of 35.5. The change of $\Omega_{\mathrm{CAL}}$ due to $T$ change $\left(\Delta \Omega_{\text {CALSST }}\right)$ was calculated as the difference between $\Omega_{\text {CALeq }}$ and $\Omega_{\text {CALSST }}$, where $\Omega_{\text {CALSST }}$ was computed from $D I C_{\text {eq }}$, a $T A$ of $2340 \mu \mathrm{mol} \mathrm{kg}$, a temperature $=13+\Delta T$, and a salinity of 35.5 .

The net effects of NCP and NCC on DIC, $\mathrm{pCO}_{2}$, and $\Omega_{\mathrm{CAL}}$ were calculated according to:

$$
\begin{aligned}
& \Delta D I C_{\text {computed }}=\Delta D I C_{\text {org }}+\Delta D I C_{\text {inorg }} \\
& \Delta \mathrm{pCO}_{2 \text { computed }}=\Delta \mathrm{pCO}_{2 \text { org }}+\Delta \mathrm{pCO}_{2 \text { inorg }} \\
& \Delta \Omega_{\mathrm{CALcomputed}}=\Delta \Omega_{\mathrm{CALorg}}+\Delta \Omega_{\mathrm{CALinorg}}+\Delta \Omega_{\mathrm{CALSST}}
\end{aligned}
$$

The observed changes of DIC, $\mathrm{pCO}_{2}$ and $\Omega_{\mathrm{CAL}}$ were calculated according to:

$$
\begin{aligned}
& \Delta D I C_{\text {observed }}=\left\langle D I C_{35.5}\right\rangle_{0-20 \mathrm{~m}}-\left\langle D I C_{35.5}\right\rangle_{80 \mathrm{~m}-\text { bottom }} \\
& \Delta \mathrm{pCO}_{2 \text { observed }}=\mathrm{pCO}_{2} @ 13^{\circ} \mathrm{C}-380 \\
& \Delta \Omega_{\mathrm{CALobserved}}=\left\langle\Omega_{\mathrm{CAL}}\right\rangle_{0-20 \mathrm{~m}}-\left\langle\Omega_{\mathrm{CAL}}\right\rangle_{80 \mathrm{~m}-\text { bottom }}
\end{aligned}
$$

[22] Air-sea $\mathrm{CO}_{2}$ fluxes $(F)$ were computed according to:

$$
F=\alpha \times k \times \Delta \mathrm{pCO}_{2 \text { air-sea }}
$$

where $\Delta \mathrm{pCO}_{2 \text { air-sea }}$ is the air-sea gradient of $\mathrm{pCO}_{2}, \alpha$ is the solubility coefficient of $\mathrm{CO}_{2}$ computed using the algorithm given by Weiss [1974], and $k$ is the gas transfer velocity computed from wind speed using the $k$-wind parameterization given by Ho et al. [2006].

[23] Wind speed data were obtained from the National Centers for Environmental Prediction reanalysis daily averages surface flux (http://www.cdc.noaa.gov/) at five grid points covering the sampled region $\left(50.475^{\circ} \mathrm{N}, 7.080^{\circ} \mathrm{W}\right.$; $50.475^{\circ} \mathrm{N}, \quad 7.120^{\circ} \mathrm{W} ; \quad 48.571^{\circ} \mathrm{N}, \quad 7.150^{\circ} \mathrm{W} ; \quad 48.571^{\circ} \mathrm{N}$, $\left.7.650^{\circ} \mathrm{W} ; 48.571^{\circ} \mathrm{N}, 8.030^{\circ} \mathrm{W}\right) . F$ was computed using daily wind speed values (average of the five grid points) for a time interval of 30 days centered on the date of the middle of the cruises. $\triangle \mathrm{pCO}_{2 \text { air-sea }}$ was computed from measured $\mathrm{pCO}_{2}$ in seawater and the monthly atmospheric $\mathrm{pCO}_{2}$ at Mace Head $\left(53.33^{\circ} \mathrm{N}, 9.00^{\circ} \mathrm{W}\right.$, Southern Ireland) obtained from the NOAA Climate Monitoring and Diagnostics Laboratory air sampling network (http://www.cmdl.noaa.gov/). Atmospheric $\mathrm{pCO}_{2}$ was converted to wet air using the water vapor algorithm given by Weiss and Price [1980].

\section{Results and Discussion}

\subsection{General Setting of the Cruises}

[24] Time series of remotely sensed surface chlorophyll-a (Chl-a) in the study area indicate that seasonal cycles of phytoplankton biomass were remarkably similar during the 3 years at the La Chapelle Bank and Goban Spur regions (Figure 2). The main spring bloom associated to diatoms peaked in mid-April, followed by a strong increase in normalized water leaving radiance at $550 \mathrm{~nm}\left(L_{\mathrm{wn}}[555]\right)$ indicative of the occurrence of coccolithophore blooms from early May to late June. Overall, higher Chl-a as well as $L_{\text {wn }}(555)$ values were observed at Goban Spur than at La Chapelle Bank during the 3 years. Some interannual variability in remotely sensed Chl-a was observed with highest concentrations in 2008 (up to $5 \mu \mathrm{g} \mathrm{L}^{-1}$ at Goban Spur). The three cruises were carried out after the main spring bloom, during the period of peak to declining $L_{\mathrm{wn}}(555)$.

[25] During the three cruises, remote sensing images revealed several patches of cold water $\left(\mathrm{SST}<14^{\circ} \mathrm{C}\right)$ along the shelf break in the whole study area (Figure 3 ) corresponding to the signature of enhanced vertical mixing due to turbulent dissipation related to the generation of internal tides [Pingree and New, 1995; Wollast and Chou, 2001]. The highest Chl-a concentrations $\left(>0.8 \mu \mathrm{g} \mathrm{L}^{-1}\right)$ at the continental margin were observed inshore of the $200 \mathrm{~m}$ isobath. The upwelled nutrient rich cold water at the shelf break, characterized by lower Chl-a values $\left(\sim 0.4 \mu \mathrm{g} \mathrm{L}^{-1}\right)$, warmed and stratified as it propagated from the shelf break both offand onshore, leading to enhanced biological activity [Wollast and Chou, 2001; Harlay et al., 2010]. As these water masses propagated further on the shelf, phytoplankton development caused nutrient depletion, hence, the highest Chl-a waters were confined close to the shelf break. The high Chl-a waters were also associated to high reflectance patches indicating the presence of coccolithophores at the end of the inorganic phase, since coccoliths that are shed from coccolithophores increase reflectance. High performance liquid chromatography (HPLC) pigment measurements (N. Van Oostende and K. Sabbe, personal communication, 
La Chapelle Bank
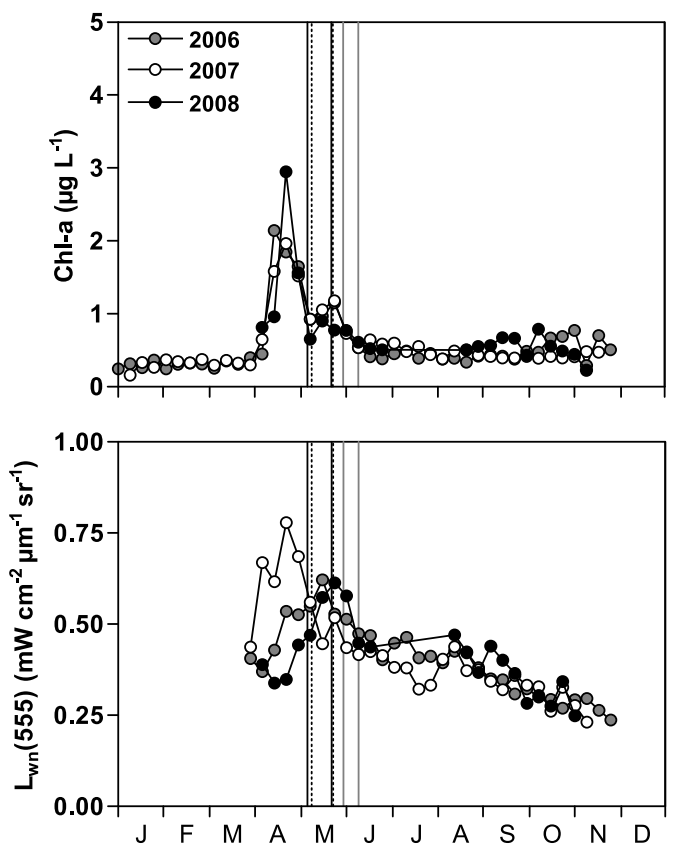

Goban Spur
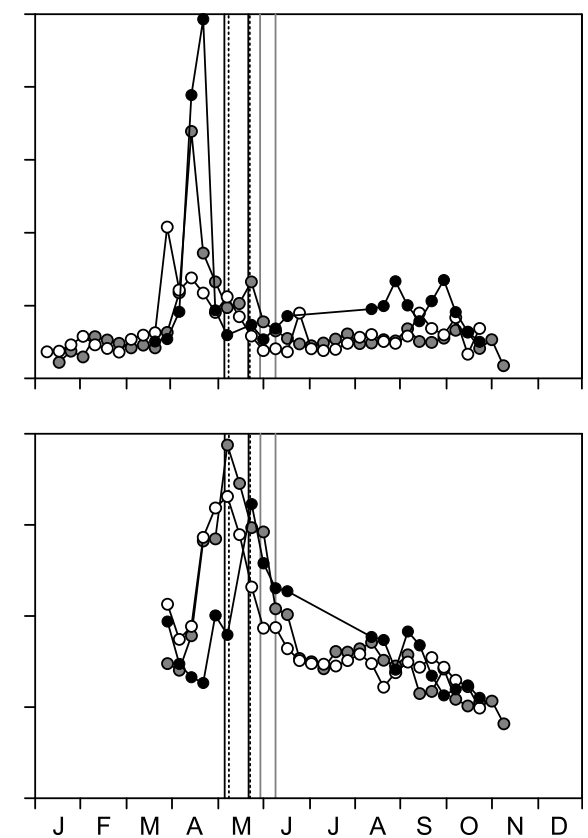

Figure 2. Time-series in 2006 (grey circles), 2007 (open circles), and 2008 (black circles) of weekly averages of Chl-a and $\mathrm{L}_{\mathrm{wn}}(555)$ at La Chapelle Bank $\left[47.0^{\circ} \mathrm{N} ; 49.0^{\circ} \mathrm{N} ; 9^{\circ} 0^{\circ} \mathrm{W} ; 6.0^{\circ} \mathrm{W}\right]$ and Goban Spur $\left[49.0^{\circ} \mathrm{N} ; 51.5^{\circ} \mathrm{N} ; 11.0^{\circ} \mathrm{W} ; 9^{\circ} \mathrm{W}\right.$ ] (Sea-viewing Wide Field-of-view Sensor (SeaWiFS), retrieved from http://reason.gsfc.nasa.gov/Giovanni/). Start and end of cruises are indicated by vertical lines (solid grey for June 2006; dotted black for May 2007; solid black for May 2008). Normalized water leaving radiance at $550 \mathrm{~nm}$ data from January to March were removed, since cloud coverage leads to biased values during wintertime (S. Groom, personal communication, 2009).

not shown) indicate that prymnesiophytes (i.e., coccolithophores) accounted, depending on the station, for $10 \%-71 \%$, $0 \%-59 \%$, and $2 \%-49 \%$ of the total Chl-a during the June 2006, May 2007, and May 2008 cruises, respectively. The other most abundant phytoplankton community in terms of total Chl-a was usually composed of diatoms, and at some rare occasions of dinoflagellates or chlorophytes. Scanning electron microscopy (SEM) of coccolithophores in samples obtained during the June 2007 and June 2008 cruises identified Emiliania huxleyi as the dominant species (N. Van Oostende and K. Sabbe, personal communication; A. Engel, personal communication).

\subsection{Distribution of $\mathbf{p C O}_{2}$ and TA in Surface Waters}

[26] The distribution of $\mathrm{pCO}_{2}$ during the three cruises was patchy and strong horizontal gradients of $\mathrm{pCO}_{2}$ were observed (Figure 4). At the continental margin, the range of $\mathrm{pCO}_{2}$ variations in surface waters was 248-270 ppm, 288342 ppm, and 250-269 ppm, during the June 2006, May 2007, and May 2008 cruises, respectively. The $\mathrm{pCO}_{2}$ values were systematically below atmospheric equilibrium $(378 \mathrm{ppm}$, $382 \mathrm{ppm}$, and 385 ppm in June 2006, May 2007, and May 2008, respectively), hence, the area acted as a sink for atmospheric $\mathrm{CO}_{2}$. Average air-sea $\mathrm{CO}_{2}$ fluxes were -9.8 , -11.9 , and $-7.4 \mathrm{mmol} \mathrm{C} \mathrm{m}^{-2} \mathrm{~d}^{-1}$ in June 2006, May 2007, and May 2008, respectively (Table 1), in agreement with air-sea $\mathrm{CO}_{2}$ fluxes reported previously in the area at this time of the year [Frankignoulle and Borges, 2001; Borges et al., 2006; Padin et al., 2009; de la Paz et al., 2010; Harlay et al., 2010].

[27] During the three cruises, TA in surface waters showed a strong nonconservative behavior with respect to salinity compared to the climatological TA-S relationship for the North Atlantic Ocean surface waters reported by Millero et al. [1998] (Figure 5). Some of the TA data points (in particular during the June 2008 cruise) were above the climatological TA-S relationship of Millero et al. [1998]. While these TA data points remained within the standard deviation of the linear fit of the climatological TA-S relationship of Millero et al. [1998] $\left( \pm 9 \mu \mathrm{mol} \mathrm{kg}{ }^{-1}\right)$, this could be due to local influence in the northern Bay of Biscay of river inputs [Kelly-Gerreyn et al., 2006] characterized by high TA values, such as the Loire river [TA $\sim 2800 \mu \mathrm{mol}$ $\mathrm{kg}^{-1}$ in the freshwater end member, Abril et al., 2003] and the Gironde river [TA $\sim 2400 \mu \mathrm{mol} \mathrm{kg}{ }^{-1}$ in the freshwater end member, Abril et al., 1999]. Yet, the nonconservative behavior of TA as a function of salinity indicated the drawdown of TA by calcification. This is consistent with the presence of coccolithophores in the area during the three cruises as indicated by the high reflectance patches in remote sensing images (Figure 3), HPLC and SEM measurements. 

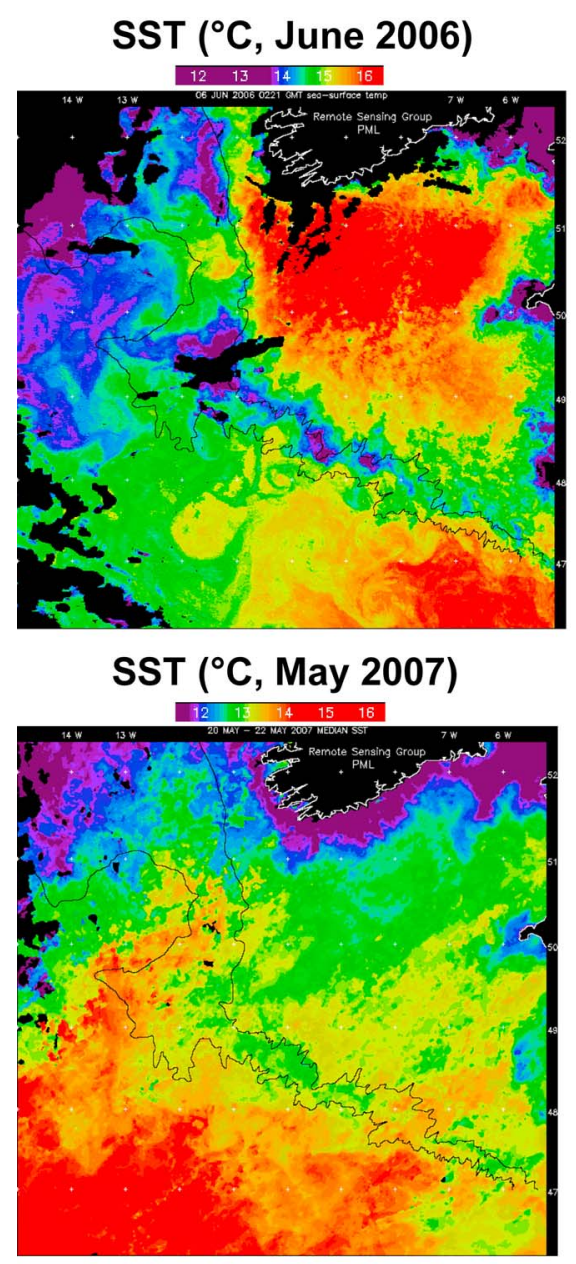

SST ( ${ }^{\circ} \mathrm{C}$, May 2008)

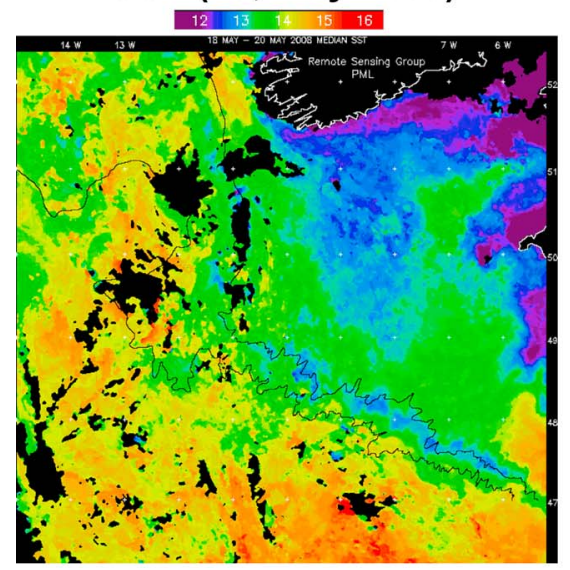

Chl-a ( $\mu \mathrm{g} \mathrm{L}^{-1}$, June 2006)

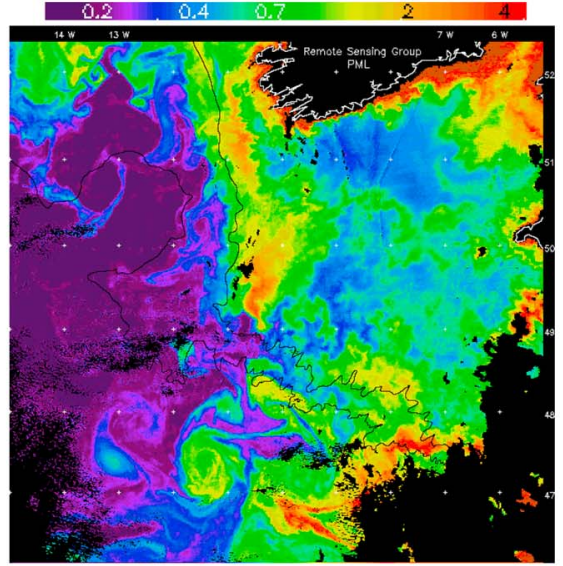

Chl-a ( $\mu \mathrm{g} \mathrm{L}^{-1}$, May 2007)

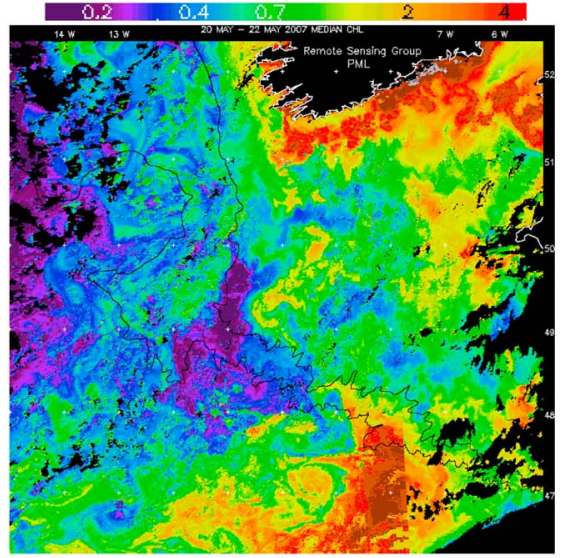

Chl-a ( $\mu \mathrm{g} \mathrm{L}^{-1}$, May 2008)

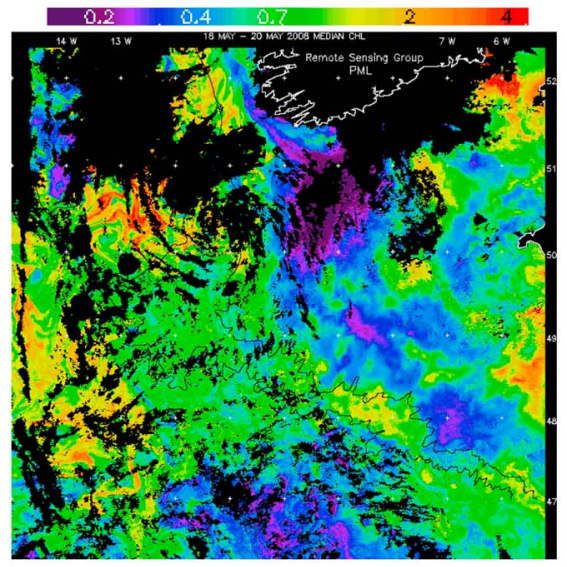

Reflectance (June 2006)

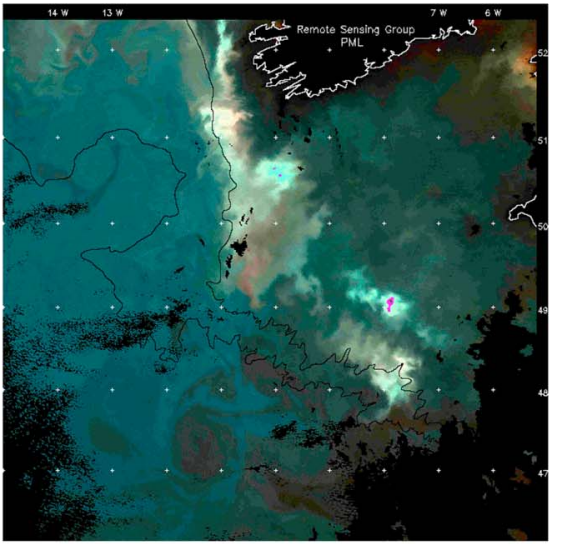

Reflectance (May 2007)

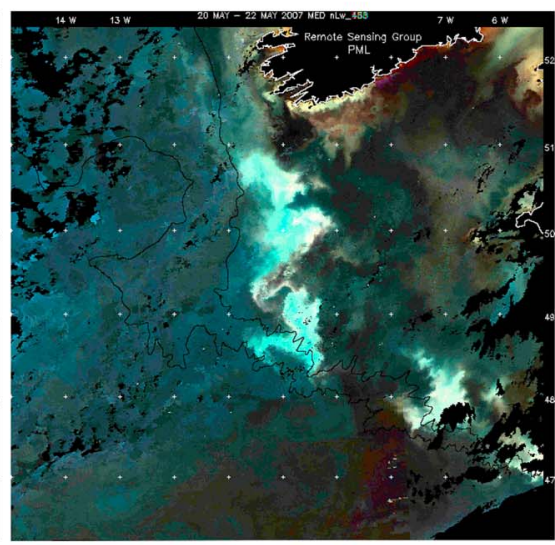

Reflectance (May 2008)

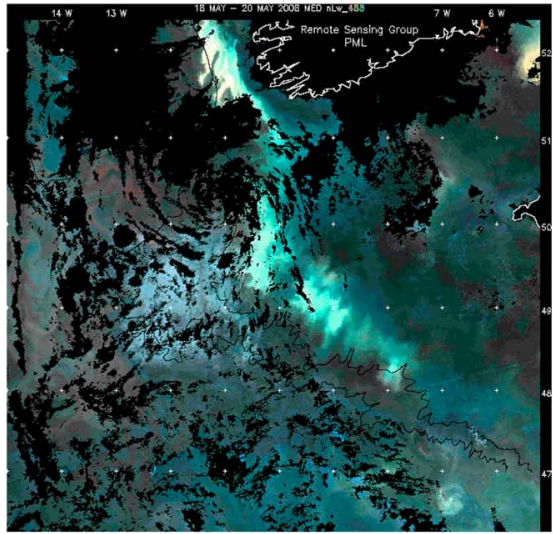

Figure 3. Remote sensing images of SST (Advanced Very High Resolution Radiometer), Chl-a (SeaWiFS), and reflectance (unitless, false-color [443, 490, and $555 \mathrm{~nm}$ bands], SeaWiFS) contemporary to the May 2006, June 2007, and 2008 cruises in the Bay of Biscay (6 May 2006; composite 20-22 May 2007; composite 18 May 2008) (courtesy of S. Groom, Remote Sensing Group of the Plymouth Marine Laboratory), and bathymetry (200 $\mathrm{m}$ and $2000 \mathrm{~m}$ isobaths). 

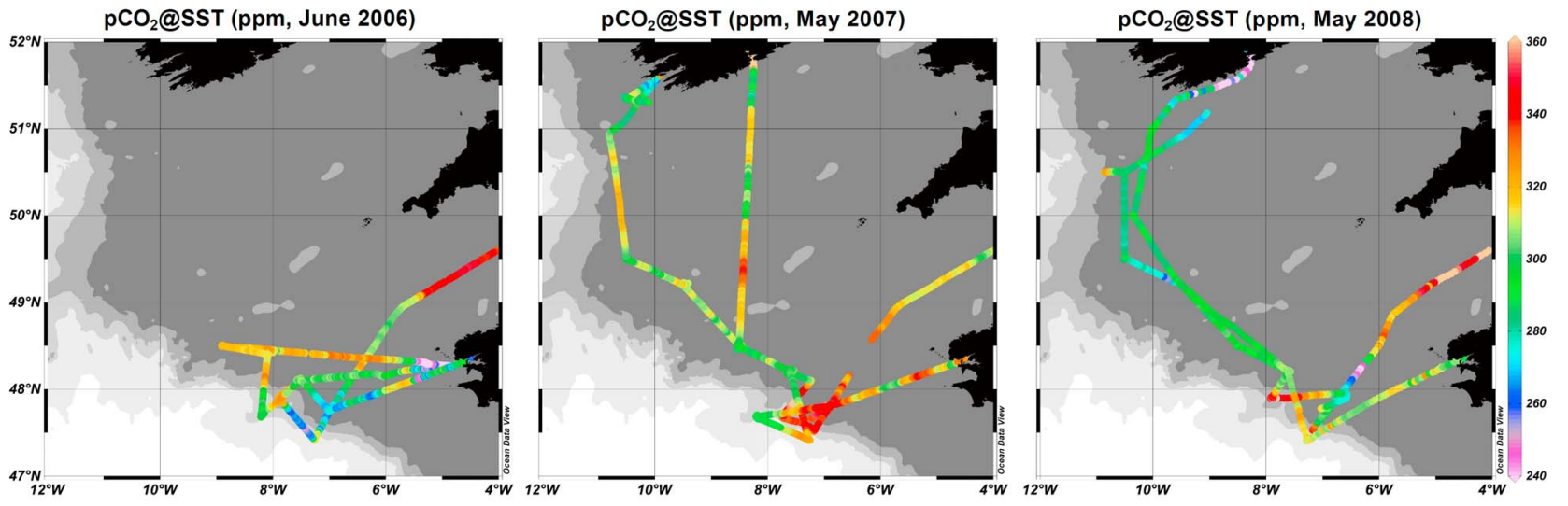

Figure 4. Distribution of $\mathrm{pCO}_{2} @ \mathrm{SST}$ in surface waters in the northern Bay of Biscay in June 2006, May 2007, and May 2008, and bathymetry $(250 \mathrm{~m}, 1000 \mathrm{~m}, 2000 \mathrm{~m}$, and $4000 \mathrm{~m}$ isobaths).

\subsection{Distribution of Variables as Function of the Degree of Stratification}

[28] Stratification is one of the most important variables controlling the intensity of primary production, and the succession of phytoplankton communities [e.g., Margalef,
1997]. Increasing stratification enhances light availability but leads to the decrease of vertical input of inorganic nutrients, imposing a succession of phytoplankton communities with variable light and inorganic nutrient requirements. Coccolithophores (and especially Emiliania huxleyi)

Table 1. Date, Position, $\triangle \mathrm{pCO}_{2 \text { air-sea, }} \mathrm{F}$, and Change of $\mathrm{F}$ Due to NCC in the Northern Bay of Biscay in June 2006, May 2007, and May 2008

\begin{tabular}{|c|c|c|c|c|c|}
\hline Date & $\begin{array}{l}\text { Longitude } \\
\left({ }^{\circ} \mathrm{W}\right)\end{array}$ & $\begin{array}{l}\text { Latitude } \\
\qquad\left({ }^{\circ} \mathrm{N}\right)\end{array}$ & $\begin{array}{l}\Delta \mathrm{pCO}_{2 \text { air-sea }} \\
\quad(\mathrm{ppm})\end{array}$ & $\begin{array}{c}\mathrm{F} \\
\left(\mathrm{mmol} \mathrm{C} \mathrm{m}^{-2} \mathrm{~d}^{-1}\right)\end{array}$ & $\begin{array}{c}\text { Change of F Due } \\
\text { to NCC }(\%)\end{array}$ \\
\hline 31 May 2006 & 7.000 & 47.749 & -109 & -13.1 & 5 \\
\hline 1 June 2006 & 7.166 & 47.533 & -100 & -12.1 & 4 \\
\hline 2 June 2006 & 7.902 & 47.901 & -59 & -7.1 & 3 \\
\hline 2 June 2006 & 7.502 & 48.100 & -85 & -10.2 & 16 \\
\hline 6 June 2006 & 8.901 & 48.500 & -55 & -6.6 & 23 \\
\hline 7 June 2006 & 8.099 & 48.400 & -67 & -8.1 & 14 \\
\hline 8 June 2006 & 7.500 & 48.100 & -73 & -8.7 & 21 \\
\hline 9 June 2006 & 7.001 & 47.750 & -107 & -12.9 & 5 \\
\hline Average & & & -82 & -9.8 & 11 \\
\hline 10 May 2007 & 6.898 & 47.800 & -34 & -5.5 & 72 \\
\hline 12 May 2007 & 7.622 & 48.202 & -86 & -13.9 & 12 \\
\hline 13 May 2007 & 8.499 & 48.498 & -73 & -11.8 & 8 \\
\hline 14 May 2007 & 9.495 & 49.204 & -71 & -11.4 & 23 \\
\hline 15 May 2007 & 10.509 & 49.500 & -85 & -13.8 & 6 \\
\hline 16 May 2007 & 10.500 & 51.344 & -94 & -15.3 & 7 \\
\hline 21 May 2007 & 8.492 & 48.505 & -84 & -13.6 & 4 \\
\hline 22 May 2007 & 7.577 & 48.228 & -88 & -14.2 & 11 \\
\hline 23 May 2007 & 7.267 & 47.417 & -60 & -9.6 & 22 \\
\hline 23 May 2007 & 8.198 & 47.681 & -93 & -15.0 & 7 \\
\hline 24 May 2007 & 7.241 & 47.774 & -39 & -6.4 & 36 \\
\hline Average & & & -73 & -11.9 & 19 \\
\hline 7 May 2008 & 6.001 & 48.499 & -72 & -6.4 & 0 \\
\hline 7 May 2008 & 7.165 & 47.533 & -43 & -3.8 & 21 \\
\hline 8 May 2008 & 6.898 & 47.801 & -92 & -8.1 & 1 \\
\hline 9 May 2008 & 7.909 & 47.898 & -36 & -3.2 & 2 \\
\hline 10 May 2008 & 7.594 & 48.204 & -89 & -7.9 & 3 \\
\hline 11 May 2008 & 8.499 & 48.501 & -93 & -8.2 & 6 \\
\hline 12 May 2008 & 9.502 & 49.199 & -116 & -10.3 & 1 \\
\hline 13 May 2008 & 10.505 & 49.498 & -103 & -9.1 & 8 \\
\hline 14 May 2008 & 10.502 & 50.502 & -101 & -8.9 & 5 \\
\hline 19 May 2008 & 9.997 & 51.003 & -92 & -8.1 & 9 \\
\hline 20 May 2008 & 10.341 & 50.002 & -96 & -8.5 & 14 \\
\hline 21 May 2008 & 9.496 & 49.202 & -88 & -7.8 & 22 \\
\hline 22 May 2008 & 7.600 & 48.200 & -76 & -6.7 & 3 \\
\hline 23 May 2008 & 7.267 & 47.418 & -69 & -6.0 & 9 \\
\hline Average & & & -83 & -7.4 & 8 \\
\hline
\end{tabular}




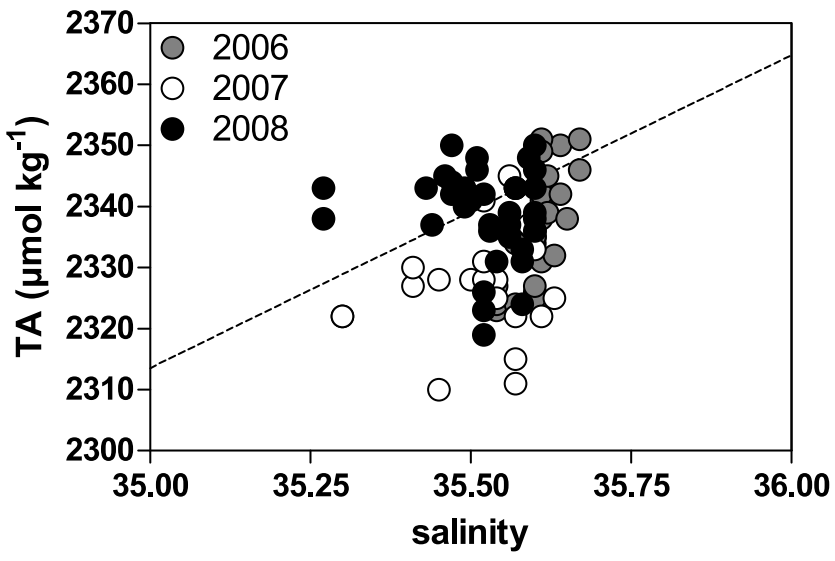

Figure 5. Variation of TA versus salinity (top $20 \mathrm{~m}$ ) in the northern Bay of Biscay in June 2006 (grey circles), May 2007 (open circles), and May 2008 (black circles). The dotted line corresponds to the climatological TA-S relationship given by Millero et al. [1998] for the surface waters of the North Atlantic Ocean.

have a high tolerance to elevated irradiances [Nanninga and Tyrrell, 1996] as well as a high affinity for inorganic [Holligan et al., 1993] and organic nutrients [Riegman et al., 2000]. Emiliania huxleyi has the ability to use organic sources for nitrogen and phosphorous when inorganic nutrients are limiting for the development of other phytoplanktonic species [Palenik and Henson, 1997; Riegman et al., 2000]. Hence, Emiliania huxleyi usually blooms in stratified and inorganic nutrient-depleted conditions typically after the blooms of diatoms [e.g., Margalef, 1997].

[29] The degree of stratification was computed as the difference between seawater density at $100 \mathrm{~m}$ depth and the seawater density at $10 \mathrm{~m}$ depth. These depths were chosen to make sure that the upper value was within the mixed layer (where density was homogeneous), and that the bottom value was below the base of the thermocline (down to $70 \mathrm{~m}$ at some stations, not shown). Variables from different stations were plotted as a function of the degree of stratification as a way of reconstructing the effect of the bloom development on seawater carbonate chemistry and other biogeochemical variables. Such an approach is useful and appropriate in the study area, where there is a more or less continuous generation of low stratified and nutrient rich waters at the continental shelf break that propagate on shelf, stratify, and host high phytoplankton biomass at the period of the year when the cruises were carried out (section 3.1). It should be noted that the changes of the biogeochemical variables as a function of the stratification degree correspond to a cumulative signal of biological activity, and these patterns do not necessarily indicate an increase of biological rates with stratification. Prior to the May 2007 cruise, a major storm occurred in the area that induced enhanced vertical mixing compared to the June 2006 and May 2008 cruises, and this might have added additional variability in the 2007 data set as a function of the degree of stratification. Hence, linear regressions of variables as a function of the degree of stratification were computed either on the basis of the 2006 and 2008 data sets or on the 2006, 2007, and 2008 data sets.

[30] The patterns of the variables in surface waters as a function of the stratification degree were remarkably consistent considering that data from three cruises carried out in different years were merged together (Figure 6). The increase of $\% \mathrm{O}_{2}$ and decrease of $\mathrm{PO}_{4}^{3-}$ were consistent with organic carbon production during the bloom development (increasing stratification). The pattern in $T A_{\text {anomaly }}$ was consistent with $\mathrm{CaCO}_{3}$ production during the bloom development (increasing stratification) of mixed phytoplanktonic communities. The strongest $T A_{\text {anomaly }}\left(-32 \mu \mathrm{mol} \mathrm{kg}{ }^{-1}\right)$ was comparable to the strongest values of $-28 \mu \mathrm{mol} \mathrm{kg} \mathrm{kg}^{-1}$ reported by Holligan et al. [1993] in the North Atlantic in June 1991, and of $-35 \mu \mathrm{mol} \mathrm{kg}^{-1}$ reported by Bates et al. [1996] in the Sargasso Sea in February 1992, but weaker than the value of $-82 \mu \mathrm{mol} \mathrm{kg}{ }^{-1}$ reported by Murata and Takizawa [2002] in the Bering Sea in October 2000. These $T A_{\text {anomaly values observed in naturally occurring blooms }}$ remain well below the $T A$ drawdown observed in confined environments with coccolithophores of $\sim 300 \mu \mathrm{mol} \mathrm{kg}^{-1}$ in mesocosms [e.g., Delille et al., 2005] and of $\sim 1000 \mu \mathrm{mol} \mathrm{kg}^{-1}$ in batch cultures [e.g., De Bodt et al., 2010]. pCO $\mathrm{CO}_{2} 13^{\circ} \mathrm{C}$ showed a decreasing pattern with stratification, indicative that the net effect on $\mathrm{pCO}_{2}$ of organic carbon production dominated over the net effect of calcification. The pattern with stratification of $\mathrm{pCO}_{2} @ \mathrm{SST}$ has lower statistical significance than that of $\mathrm{pCO}_{2} @ 13^{\circ} \mathrm{C}$ due to the increase of SST with stratification and subsequent effect on the $\mathrm{CO}_{2}$ solubility and $\mathrm{pCO}_{2} @$ SST. DIC decreased during the bloom development (increasing stratification) due to the combined effect of NCC and NCP, as discussed hereafter. Although the linear regression has a low statistical significance, the general increasing pattern of $\Omega_{\mathrm{CAL}}$ during the bloom development (increasing stratification) suggests that the combined (increasing) effect of NCP and SST change dominated over the (decreasing) effect of NCC, as discussed hereafter. Also, the values of $\Omega_{\mathrm{CAL}}$ were higher than the wintertime value of $\sim 3.7$ (computed from a $T A$ of $2340 \mu \mathrm{mol} \mathrm{kg}{ }^{-1}$, a salinity of 35.5 , a $S S T$ of $12^{\circ} \mathrm{C}$ and $\mathrm{pCO}_{2}$ at atmospheric equilibrium, based on wintertime data in the area reported by Frankignoulle and Borges [2001]). This shows that NCP increased $\Omega_{\mathrm{CAL}}$ values with regards to wintertime values. A temperature increase from the wintertime value of $12^{\circ} \mathrm{C}$ to $13^{\circ} \mathrm{C}$ (average SST during the cruises) can only account for an increase of $\Omega_{\mathrm{CAL}}$ of $3 \%$, while the increase between observed $\Omega_{\mathrm{CAL}}$ values and the wintertime $\Omega_{\mathrm{CAL}}$ value ranged between $9 \%$ and $34 \%$.

[31] The low values of $\mathrm{pCO}_{2}$ and DIC in surface waters observed in the area during the cruises could be in part due to NCP during the diatom blooms that occurred prior to the cruises and peaked in mid-April (Figure 2). However, mixing at the shelf break (section 3.1) also induced the increase of $\mathrm{pCO}_{2}$ and DIC in surface waters as indicated by the high values of these quantities for the lowest degree of stratification (Figure 6). The mixing at the shelf break and injection of nutrients to surface waters are assumed to be the factors that trigger the coccolithophore blooms in the area at the period of the year the cruises were carried out [Harlay et al., 2010]. Since the stations sampled over the continental 

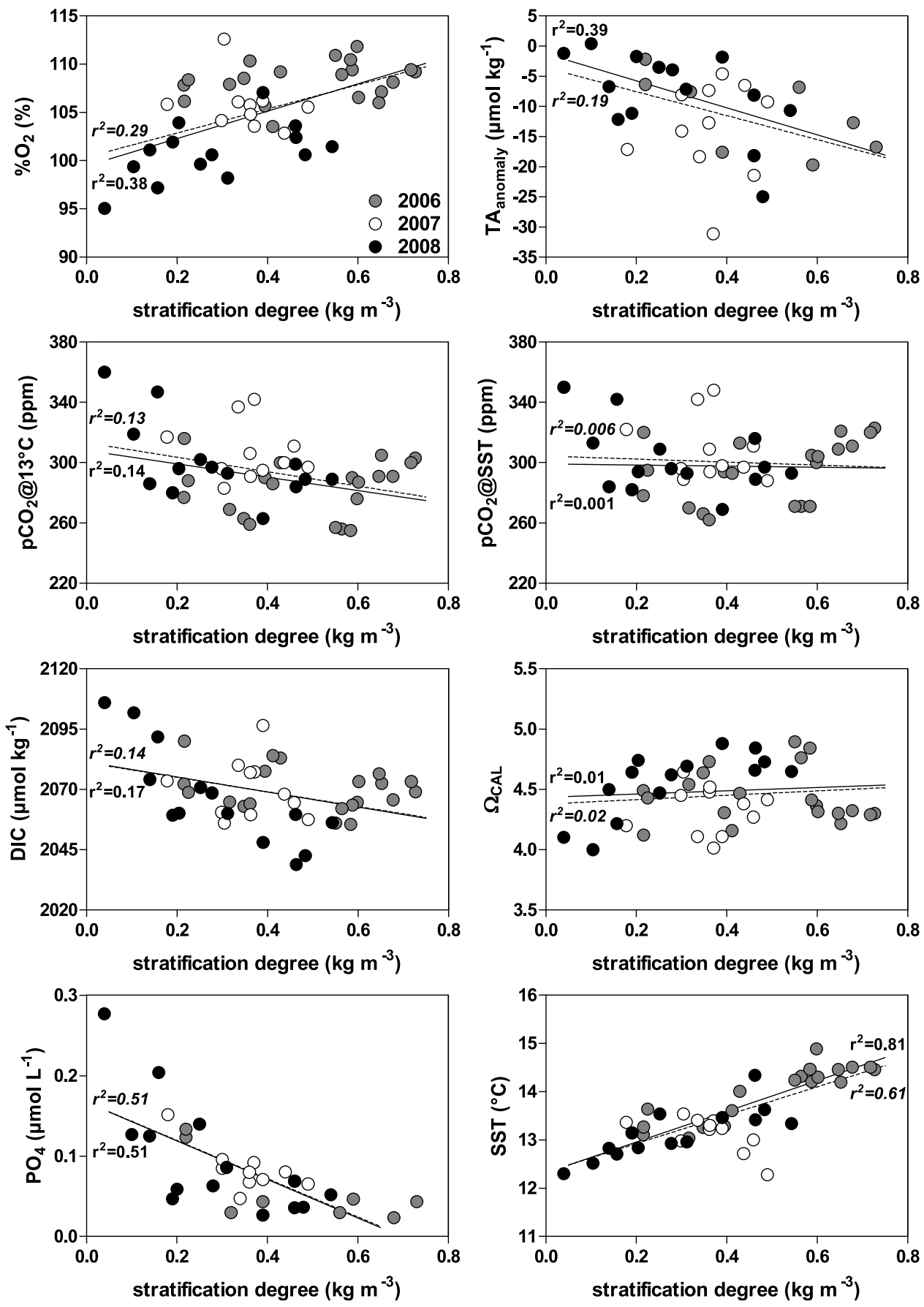

Figure 6. Average values in surface waters (top $20 \mathrm{~m}$ ) of $\% \mathrm{O}_{2}, \mathrm{TA}_{\text {anomaly }}, \mathrm{DIC}, \Omega_{\mathrm{CAL}}$, and $\mathrm{PO}_{4}^{3-}$, and underway pCO $\mathrm{pC}_{2} @ 13^{\circ} \mathrm{C}$ and $\mathrm{pCO}_{2} @ \mathrm{SST}$, and SST $(2 \mathrm{~m})$ as a function of the degree of stratification, during the June 2006 (grey circles), May 2007 (open circles), and May 2008 (black circles) cruises in the northern Bay of Biscay. The solid line corresponds to the linear regression based on the 2006 and 2008 data sets (corresponding $r^{2}$ is not italicized), the dotted line corresponds to the linear regression based on the 2006, 2007, and 2008 data sets (corresponding $r^{2}$ is italicized).

shelf and slope were close to the shelf break, we assume that the sampled water masses were derived from the cold and nutrient rich source waters at the shelf break. Hence, we also assume that the patterns of biogeochemical variables as a function of stratification in Figure 6, and the effects of NCP and NCC on seawater carbonate chemistry evaluated hereafter are mainly related to the activity of the recently bloomed mixed phytoplanktonic assemblages dominated by coccolithophores. 


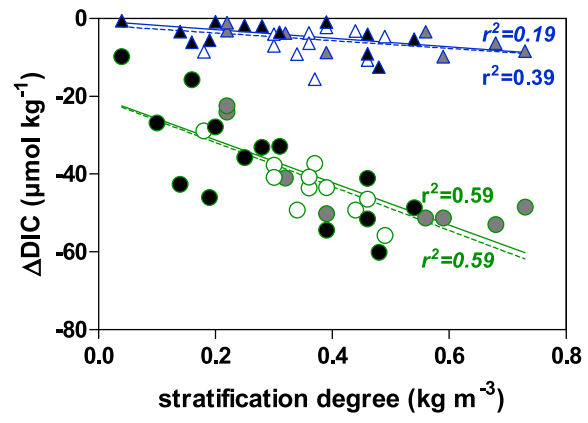

$\Delta \mathrm{DIC}$ org 2006

- $\triangle \mathrm{DIC}_{\text {org }} 2007$

- $\triangle \mathrm{DIC}$ org 2008

$\triangle \Delta \mathrm{DIC}$ inorg 2006

$\triangle \Delta \mathrm{DIC}_{\text {inorg }} 2007$

$\Delta \Delta \mathrm{DIC}_{\text {inorg }} 2008$

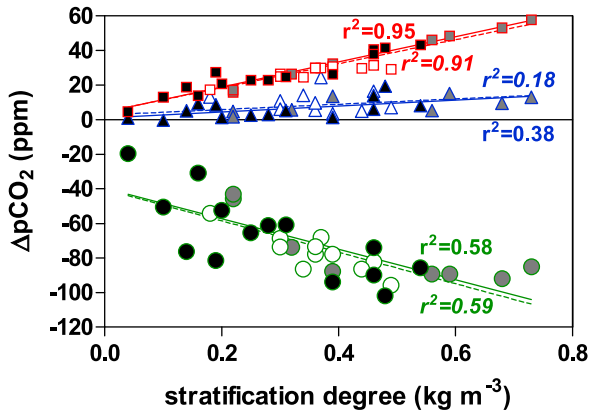

- $\triangle \mathrm{pCO}_{2 \text { org }} 2006$

- $\triangle \mathrm{pCO}_{2 \text { org }} 2007$

- $\triangle \mathrm{pCO}_{2 \text { org }} 2008$

$\triangle \Delta \mathrm{pCO}_{2 \text { inorg }} 2006$

$\triangle \Delta \mathrm{pCO}_{2 \text { inorg }} 2007$

- $\triangle \mathrm{pCO}_{2 \text { inorg }} 2008$

- $\triangle \mathrm{pCO}_{2 S \mathrm{ST}} 2006$

a $\triangle \mathrm{pCO}_{2 \mathrm{SST}} 2007$

- $\triangle \mathrm{pCO}_{2 S \mathrm{ST}} 2008$

stratification degree $\left(\mathrm{kg} \mathrm{m}^{-3}\right)$

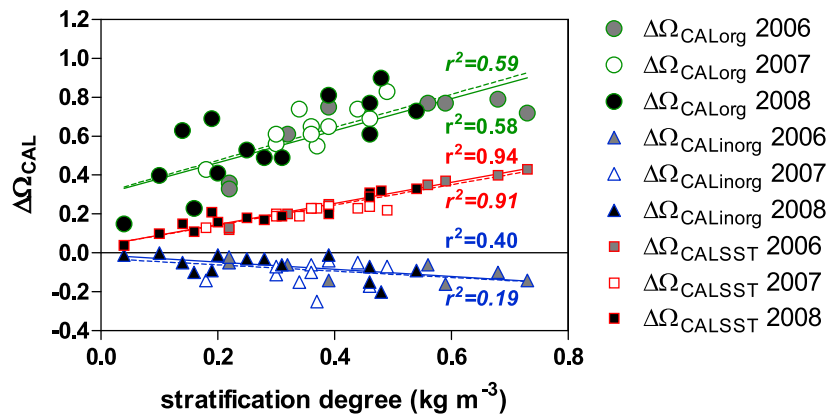

Figure 7. The $\Delta \mathrm{DIC}_{\mathrm{org}}, \Delta \mathrm{DIC}_{\text {inorg }}, \Delta \mathrm{pCO}_{2 \text { org }}, \Delta \mathrm{pCO}_{2 \text { inorg }}$, $\Delta \mathrm{pCO}_{2 \mathrm{SST}}, \Delta \Omega_{\mathrm{CALorg}}, \Delta \Omega_{\mathrm{CALinorg}}$, and $\Delta \Omega_{\mathrm{CALSST}}$ as a function of the degree of stratification, during the June 2006 (grey symbols), May 2007 (open symbols), and May 2008 (black symbols) cruises in the northern Bay of Biscay. The solid line corresponds to the linear regression based on the 2006 and 2008 data sets (corresponding $r^{2}$ is not italicized), the dotted line corresponds to the linear regression based on the 2006, 2007, and 2008 data sets (corresponding $r^{2}$ is italicized).

\subsection{Evaluation of the Effect of NCP, NCC, and SST on DIC, $\mathrm{pCO}_{2}$, and $\Omega_{\mathrm{CAL}}$}

[32] The cumulative effects of NCP, NCC, and SST change on DIC, $\mathrm{pCO}_{2}$ and $\Omega_{\mathrm{CAL}}$ were evaluated as described in section 2.3. $\triangle \mathrm{DIC}_{\text {org }}$ and $\Delta \mathrm{pCO}_{2 \text { org }}$ decreased, and $\Delta \Omega_{\text {CALorg }}$ increased with increasing stratification, consistent with a cumulative effect of NCP as the water mass stratified and the bloom developed (Figure 7). $\triangle \mathrm{DIC}_{\text {inorg }}$ and $\Delta \Omega_{\text {CALinorg }}$ decreased, and $\Delta \mathrm{pCO}_{2 \text { inorg }}$ increased, with increasing stratification, consistent with a cumulative effect of NCC as the water mass stratified and the bloom developed. $\Delta \mathrm{pCO}_{2 \text { SST }}$ and $\Delta \Omega_{\mathrm{CALSST}}$ increased with increasing stratification, consistent with the warming of surface waters as the water mass stratified. The cumulative effect of NCP on DIC as well as on $\mathrm{pCO}_{2}$ was stronger $(\triangle \mathrm{DIC}$ org down to $-60 \mu \mathrm{mol} \mathrm{kg}^{-1}$ and $\Delta \mathrm{pCO}_{2 \text { org }}$ down to $\left.-100 \mathrm{ppm}\right)$ than the effect of NCC $\left(\triangle D I C_{\text {inorg }}\right.$ down to $-20 \mu \mathrm{mol} \mathrm{kg}^{-1}$ and $\triangle \mathrm{pCO}_{2 \text { inorg }}$ up to $+20 \mathrm{ppm}$ ). The cumulative effect of NCC on $\mathrm{pCO}_{2}$ was also weaker than the effect of SST change $\left(\Delta \mathrm{pCO}_{2 \mathrm{SST}}\right.$ up to $\left.+60 \mathrm{ppm}\right)$. The highest $\Delta \mathrm{pCO}_{2 \text { inorg }}$ values we report were close to maximal values reported by Robertson et al. [1994] in northeast North Atlantic Ocean in June 1991 ( $15 \mathrm{ppm})$, and those given by the model of Buitenhuis et al. [2001] ( $25 \mathrm{ppm})$ calibrated with data from the northern North Sea in June 1993 [Buitenhuis et al., 1996]. However, the $\triangle \mathrm{pCO}_{2 \text { inorg }}$ values we report were lower than the highest value reported by Murata and Takizawa [2002] in the Bering Sea in October $2000(\sim 100 \mathrm{ppm})$. This is mainly due to very high TA drawdown $\left(-82 \mu \mathrm{mol} \mathrm{kg}{ }^{-1}\right)$ [Murata and Takizawa, 2002], and to a lesser extent due to the lower seawater buffering capacity in the Bering Sea (salinity 32). The cumulative effect of NCP as well as SST change on $\Delta \Omega_{\mathrm{CAL}}$ was stronger $\left(\Delta \Omega_{\mathrm{CALorg}}\right.$ up to +0.9 , $\Delta \Omega_{\text {CALSST }}$ up to +0.4$)$ than the effect of NCC $\left(\Delta \Omega_{\text {CALinorg }}\right.$ down to -0.3$)$.

[33] The $\Delta \mathrm{DIC}_{\text {inorg }}: \Delta \mathrm{DIC}_{\text {org }}$ ratio increased with stratification (Figure 8), in agreement with the life cycle of coccolithophores. As the water mass stratifies and nutrients become depleted in surface waters, coccolithophores shift from the organic carbon production and growth phase to the stationary and calcification phase [Fernández et al., 1993; Paasche and Brubak, 1994; Paasche, 2002; Delille et al., $2005]$. The $\Delta \mathrm{DIC}_{\text {inorg }}: \Delta \mathrm{DIC}$ org values $(0.00$ to 0.42 , on average 0.13 for the three cruises) were in relatively good agreement with $\mathrm{C}: \mathrm{P}$ values based on calcification and primary production rates derived from ${ }^{14} \mathrm{C}$ incubations reported

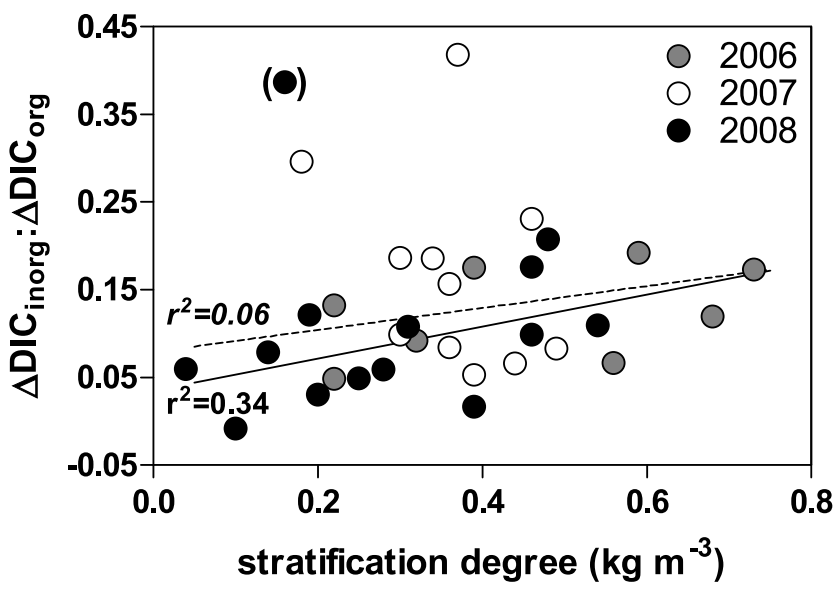

Figure 8. The $\Delta \mathrm{DIC}_{\text {inorg }}: \Delta \mathrm{DIC}_{\mathrm{org}}$ as a function of the degree of stratification, during the June 2006 (grey circles), May 2007 (open circles), and May 2008 (black circles) cruises in the northern Bay of Biscay. The solid line corresponds to the linear regression based on the 2006 and 2008 data sets (corresponding $r^{2}$ is not italicized), the dotted line corresponds to the linear regression based on the 2006, 2007, and 2008 data sets (corresponding $r^{2}$ is italicized). The data point in brackets was assumed to be an outlier and was excluded from the linear regression analysis. 

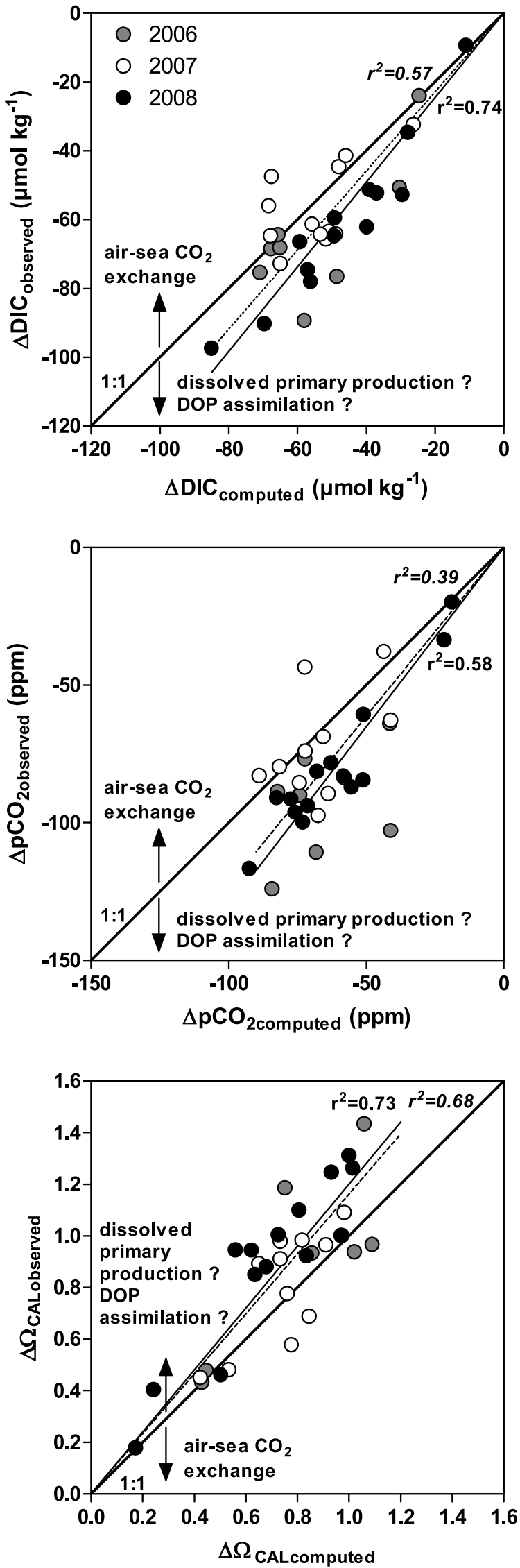

during several studies in the North Atlantic Ocean: 0.140.19 in the northeast North Atlantic Ocean in June 1991 [Fernández et al., 1993], 0.03-0.18 in the northern North Sea in July 1993 [van der Wal et al., 1995], 0.14-0.16 in the northern North Sea in July 1994 [Marañon and González, 1997], 0.03-0.18 in the northern North Sea in June 1999 [Rees et al., 2002], 0.02-0.31 in the northern Bay of Biscay in June 2004 [Harlay et al., 2010].

[34] The much larger effect of NCP than NCC on seawater carbonate chemistry is confirmed by the value of the Revelle factor of 8.4 in the top $30 \mathrm{~m}$ of the water column (for the whole data set). This value is closer to the theoretical value of 10.0 if only DIC uptake and release by net organic carbon production and degradation occurred in the water column, than the theoretical value of -7.5 if only DIC uptake and release by $\mathrm{CaCO}_{3}$ precipitation and dissolution occurred in the water column (computed for a temperature of $13^{\circ} \mathrm{C}$, salinity of $35.5, \mathrm{pCO}_{2}$ of $300 \mathrm{ppm}$, and TA of $2340 \mu \mathrm{mol} \mathrm{kg}{ }^{-1}$ ) [Frankignoulle, 1994]. Based on the Revelle factor computed from measured profiles in the top $30 \mathrm{~m}$ of the water column from the whole data set (8.4), we evaluated theoretically the $\mathrm{C}: \mathrm{P}$ ratio yielding a value of 0.12 , in close agreement with the average $\Delta \mathrm{DIC}_{\text {inorg }}: \Delta \mathrm{DIC}_{\text {org }}$ ratio $(0.13)$ derived independently.

[35] The computed changes of DIC, $\mathrm{pCO}_{2}$, and $\Omega_{\mathrm{CAL}}$ $\left(\Delta \mathrm{DIC}_{\text {computed }}, \Delta \mathrm{pCO}_{2 \text { computed }}\right.$, and $\Delta \Omega_{\mathrm{CALcomputed}}$, respectively) were remarkably consistent with the observed changes of DIC, $\mathrm{pCO}_{2}$, and $\Omega_{\mathrm{CAL}}\left(\Delta \mathrm{DIC}_{\text {observed }}, \Delta \mathrm{pCO}_{2 \text { observed }}\right.$, and $\Delta \Omega_{\text {CALobserved, }}$ respectively), considering that these quantities were evaluated independently (Figure 9). Yet, the values of $\triangle \mathrm{DIC}_{\text {observed }}$ and $\triangle \mathrm{pCO}_{2 \text { observed }}$ were almost always systematically lower than the values of $\triangle \mathrm{DIC}_{\text {computed, }}$ $\Delta \mathrm{pCO}_{2 \text { computed, }}$ and the values of $\Delta \Omega_{\mathrm{CALobserved}}$ were almost always systematically higher than the values of $\Omega_{\text {CALcomputed }}$. This could indicate that additional processes affecting seawater carbonate chemistry dynamics in surface waters were not taken into account in the computations. First, phosphorous was assumed to be assimilated by phytoplankton exclusively as $\mathrm{PO}_{4}^{3-}$, however, coccolithophores can rely on dissolved organic phosphorous (DOP) to meet part of their phosphorous requirements [Egge and Heimdal, 1994; Paasche, 2002; Lessard et al., 2005]. Secondly, in low or depleted nutrient conditions, a significant amount of carbon fixed by photosynthesis is released as dissolved organic carbon (documented for coccolithophores by Fernández et al. [1996] and Engel et al. [2004a, 2004b]), which cannot be accounted for in our computations since it is independent of nutrient assimilation (carbon overconsump-

Figure 9. The $\triangle \mathrm{DIC}_{\text {observed }}$ versus $\Delta \mathrm{DIC}_{\text {computed }}$, $\Delta \mathrm{pCO}_{2 \text { observed }}$ versus $\Delta \mathrm{pCO}_{2 \text { computed }}$, and $\Delta \Omega_{\mathrm{CALobserved}}$ versus $\Delta \Omega_{\text {CALcomputed }}$ during the June 2006 (grey circles), May 2007 (open circles), and May 2008 (black circles) cruises in the northern Bay of Biscay. The solid line corresponds to the linear regression (forced through 0) based on the 2006 and 2008 data sets (corresponding $r^{2}$ is not italicized), the dotted line corresponds to the linear regression (forced through 0) based on the 2006, 2007, and 2008 data sets (corresponding $r^{2}$ is italicized). The 1:1 line is in bold. 
tion) [e.g., Toggweiller, 1993; Anderson and Sarmiento, 1994; Banse, 1994]. A significant amount of dissolved primary production in the study area is consistent with the high TEP concentrations reported during the cruises [Harlay et al., 2009; J. Harlay, C. De Bodt, and L. Chou, unpublished data, 2009]. Both these explanations are consistent with the fact that the differences between observed and computed $\Delta \mathrm{DIC}, \Delta \mathrm{pCO}_{2}$, and $\Delta \Omega_{\mathrm{CAL}}$ increased toward the strongest changes (Figure 9) which correspond to the most stratified and nutrient-depleted conditions (Figure 8).

\subsection{Effect of Calcification on Air-Sea $\mathrm{CO}_{2}$ Fluxes}

[36] Air-sea $\mathrm{CO}_{2}$ fluxes were computed at each sampled station (Table 1), and the cumulative effect of NCC on airsea $\mathrm{CO}_{2}$ fluxes was evaluated by recomputing the air-sea $\mathrm{CO}_{2}$ fluxes with $\Delta \mathrm{pCO}_{2 \text { air-sea }}$ from which $\Delta \mathrm{pCO}_{2 \text { inorg }}$ was removed. The cumulative effect of $\mathrm{NCC}$ in decreasing the $\mathrm{CO}_{2}$ sink in the study area ranged between $0 \%$ and $72 \%$ depending on the station, but on average it was small, $\sim 12 \%$. If this finding is confirmed in other oceanic regions, it would imply that the potential feedback on increasing atmospheric $\mathrm{CO}_{2}$ of the projected decrease of pelagic calcification [e.g., Gehlen et al., 2007; Ridgwell et al., 2007; Hofmann and Schellnhuber, 2009] due to thermodynamic $\mathrm{CO}_{2}$ "production" from calcification is probably minor, compared to the potential feedback related to the increase of NCP and carbon export [e.g., Riebesell et al., 2007].

\section{Conclusions}

[37] We report a data set of seawater carbonate chemistry obtained during blooms of the coccolithophore Emiliania huxleyi at the continental margin of the northern Bay of Biscay. Physical settings were the major factors controlling phytoplankton dynamics under the springtime high irradiance conditions. The cold, nutrient rich upwelled water at the shelf break moved over the shelf, warmed and stratified and then became depleted in nutrients, constraining the bloom close to the shelf break. Coccolithophores were present during these cruises as testified by high reflectance patches in remote sensed images, HPCL and SEM measurements. On the basis of HLPC measurements, coccolithophores accounted up to $70 \%$ of total Chl-a. Calcification by coccolithophores led to a marked drawdown of TA. Yet, the decrease of DIC (and increase of $\mathrm{pCO}_{2}$ ) due to $\mathrm{NCC}$ was overwhelmingly lower than the decrease of $\mathrm{DIC}$ and $\mathrm{pCO}_{2}$ due to $\mathrm{NCP}\left(\mathrm{NCC}: \mathrm{NCP}\left[\triangle \mathrm{DIC}_{\text {inorg }}: \triangle \mathrm{DIC}_{\text {org }}\right]\right.$ ratios, on average 0.13 for the three cruises). The NCC:NCP $\left(\triangle \mathrm{DIC}_{\text {inorg }}: \Delta \mathrm{DIC}_{\mathrm{org}}\right)$ ratios could in fact be lower, since the computed effect of NCP on DIC was probably underestimated due DOP assimilation and/or dissolved primary production (carbon overconsumption).

[38] The overall effect of NCC in decreasing the $\mathrm{CO}_{2}$ sink in the area during the cruises was low (on average $\sim 12 \%$ ). The primary production and calcification rates based on ${ }^{14} \mathrm{C}$ incubations measured in the study area [Harlay et al., 2010; J. Harlay, unpublished data, 2009] are consistent with those typically reported in literature in the North Atlantic Ocean during blooms of coccolithophores [Fernández et al., 1993; van der Wal et al., 1995; Marañon and González, 1997;
Rees et al., 2002]. The NCC:NCP ( $\left.\Delta \mathrm{DIC}_{\text {inorg }}: \Delta \mathrm{DIC}_{\mathrm{org}}\right)$ ratios are also consistent with those reported in literature for the North Atlantic Ocean. The North Atlantic Ocean is one of the main regions of the global ocean where coccolithophore blooms are the most intense and recurrent [Brown and Yoder, 1994; Balch et al., 2005, 2007]. Also, Emiliania huxleyi is the most abundant and ubiquitous coccolithophore in the modern ocean [Paasche, 2002]. Hence, if one assumes that the overall low effect of NCC in decreasing the $\mathrm{CO}_{2}$ sink is a general feature in naturally occurring blooms in the global ocean, then the potential feedback on increasing atmospheric $\mathrm{CO}_{2}$ of the projected decrease of pelagic calcification [e.g., Gehlen et al., 2007; Ridgwell et al., 2007; Hofmann and Schellnhuber, 2009] due to thermodynamic $\mathrm{CO}_{2}$ "production" from calcification is probably minor. Furthermore, in naturally occurring blooms, the cumulative effect of NCP leads to an increase of $\Omega_{\mathrm{CAL}}$ above wintertime values (at or close to $\mathrm{CO}_{2}$ atmospheric equilibrium). Hence, a future increase of NCP [e.g., Riebesell et al., 2007] could to some extent counteract the effect of ocean acidification on $\Omega_{\mathrm{CAL}}$, in addition to the predicted effect of SST increase on $\Omega_{\mathrm{CAL}}$ [Cao et al., 2007; McNeil and Matear, 2007].

[39] Acknowledgments. We are grateful to the officers and crewmembers of the R.V. Belgica and to J. Backers, J.-P. De Blauw and G. Deschepper (Unit of the North Sea Mathematical Models) for assistance during the cruises, to S. Groom (Remote Sensing Group of the Plymouth Marine Laboratory) for providing remote sensing images, to N. Van Oostende and K. Sabbe (Ghent University) for providing the HPLC and SEM data, to A. Engel (Alfred Wegener Institute) for additional SEM data, to M.-V. Commarieu for analytical assistance, and to P. Boyd (Associate Editor) and two anonymous reviewers for encouraging comments on the previous version of the ms. This work was carried out in the frame of Belgian Science Policy project "Role of pelagic calcification and export of carbonate production in climate change" (PEACE, SD/CS/03), and contributes to the European Integrated Project "Toward an integrated marine carbon sources and sinks assessment" (CARBOOCEAN, 511176). AVB and BD are research associates at the Fonds National de la Recherche Scientifique. The first and last authors equally contributed to data analysis and manuscript drafting.

\section{References}

Abril, G., H. Etcheber, P. Le Hir, P. Bassoulet, B. Boutier, and M. Frankignoulle (1999), Oxic/anoxic oscillations and organic carbon mineralization in an estuarine maximum turbidity zone (The Gironde, France), Limnol. Oceanogr., 44(5), 1304-1315.

Abril, G., H. Etcheber, B. Delille, M. Frankignoulle, and A. V. Borges (2003), Carbonate dissolution in the turbid and eutrophic Loire estuary, Mar. Ecol.-Prog. Ser., 259, 129-138.

Anderson, L. A., and J. L. Sarmiento (1994), Redfield ratios of remineralization determined by nutrient data analysis, Global Biogeochem. Cycles, 8(1), 65-80, doi:10.1029/93GB03318.

Archer, D. E., H. Kheshgi, and E. Maier-Reimer (1998), The dynamics of fossil fuel $\mathrm{CO}_{2}$ neutralization by marine $\mathrm{CaCO}_{3}$, Global Biogeochem. Cycles, 12(2), 259-276, doi:10.1029/98GB00744.

Armstrong, R. A., C. Lee, J. I. Hedges, S. Honjo, and S. G. Wakeham (2002), A new, mechanistic model for organic carbon fluxes in the ocean: based on the quantitative association of POC with ballast minerals, Deep Sea Res. II, 49, 219-236.

Bacastow, R., and E. Maier-Reimer (1990), Ocean-circulation model of the carbon cycle, Clim. Dyn., 4, 95-125.

Balch, W. M., H. R. Gordon, B. C. Bowler, D. T. Drapeau, and E. S. Booth (2005), Calcium carbonate measurements in the surface global ocean based on Moderate-Resolution Imaging Spectroradiometer data, J. Geophys. Res., 110, C07001, doi:10.1029/2004JC002560. 
Balch, W. M., D. Drapeau, B. Bowler, and E. Booth (2007), Prediction of pelagic calcification rates using satellite measurements, Deep Sea Res. II 54, 478-495.

Banse, K. (1994), Uptake of inorganic carbon and nitrate by marine plankton and the Redfield Ratio, Global Biogeochem. Cycles, 8(1), 81-84, doi:10.1029/93GB02865.

Barker, S., J. A. Higgins, and H. Elderfield (2003) The future of the carbon cycle: Review, calcification response, ballast and feedback on atmospheric $\mathrm{CO}_{2}$, Phil. Trans. R. Soc. London, 361, 1977-1999.

Bates, N. R., A. F. Michaels, and A. H. Knap (1996), Alkalinity changes in the Sargasso Sea: Geochemical evidence of calcification?, Mar. Chem., 51, 347-358.

Beaufort, L., I. Probert, and N. Buchet (2007), Effects of acidification and primary production on coccolith weight: Implications for carbonate transfer from the surface to the deep ocean, Geochem. Geophys. Geosyst., 8 , Q08011, doi:10.1029/2006GC001493.

Benson, B. B., and D. Krause (1984), The concentration and isotopic fractionation of oxygen dissolved in freshwater and seawater in equilibrium with the atmosphere, Limnol. Oceanogr., 29, 620-632.

Berelson, W. M., W. M. Balch, R. Najjar, R. A. Feely, C. Sabine, and $\mathrm{K}$. Lee (2007), Relating estimates of $\mathrm{CaCO}_{3}$ production, export, and dissolution in the water column to measurements of $\mathrm{CaCO}_{3}$ rain into sediment traps and dissolution on the sea floor: A revised global carbonate budget, Global Biogeochem. Cycles, 21, GB1024, doi:10.1029/2006GB002803.

Borges, A. V., L.-S. Schiettecatte, G. Abril, B. Delille, and F. Gazeau (2006), Carbon dioxide in European coastal waters, Estuar. Coast. Shelf S., 70(3), 375-387.

Brewer, P. G., and J. C. Goldman (1976), Alkalinity changes generated by phytoplankton growth, Limnol. Oceanogr., 21, 108-117.

Brown, C. W., and J. A. Yoder (1994), Coccolithophorid blooms in the global ocean, J. Geophys. Res., 99(C4), 7467-7482 doi:10.1029/ 93JC02156.

Buitenhuis, E., J. van Bleijswijk, D. Bakker, and M. Veldhuis (1996), Trends in inorganic and organic carbon in a bloom of Emiliania huxleyi in the North Sea, Mar. Ecol.-Prog. Ser., 143, 271-282.

Buitenhuis, E., P. van der Wal, and H. de Baar (2001), Blooms of Emiliania huxleyi are sinks of atmospheric carbon dioxide; a field and mesocosm study derived simulation, Global Biogeochem. Cycles, 15(3), 577-588, doi:10.1029/2000GB001307.

Caldeira, K., and M. E. Wickett (2003), Anthropogenic carbon and ocean $\mathrm{pH}$, Nature, 425, 365.

Cao, L., K. Caldeira, and A. K. Jain (2007), Effects of carbon dioxide and climate change on ocean acidification and carbonate mineral saturation, Geophys. Res. Lett., 34, L05607, doi:10.1029/2006GL028605.

De Bodt, C., N. Van Oostende, J. Harlay, K. Sabbe, and L. Chou (2010), Individual and interacting effects of pCO2 and temperature on Emiliania huxleyi calcification: study of the calcite production, the coccolith morphology and the coccosphere size, Biogeosciences, 7, 1401-1412.

de la Paz, M., X. A. Padín, A. F. Ríos, and F. F. Pérez (2010), Surface fCO variability in the Loire plume and adjacent shelf waters: High spatiotemporal resolution study using ships of opportunity, Mar. Chem., $118,108-118$

Delille, B., et al. (2005), Response of primary production and calcification to changes of $\mathrm{pCO}_{2}$ during experimental blooms of the coccolithophorid Emiliania huxleyi, Global Biogeochem. Cycles, 19, GB2023, doi:10.1029/2004GB002318.

Dickson, A. G. (1993), pH buffers for sea water media based on the total hydrogen ion concentration scale, Deep-Sea Res. A, 40, 107-118.

Dickson, A. G., and F. J. Millero (1987), A comparison of the equilibrium constants for the dissociation of carbonic acid in seawater media, DeepSea Res. A, 34, 1733-1743.

Doney, S. C., V. J. Fabry, R. A. Feely, and J. A. Kleypas (2009), Ocean acidification: The other $\mathrm{CO}_{2}$ problem, Ann. Rev. Mar. Sci., 1, 169-192.

Egge, J. K., and B. R. Heimdal (1994), Blooms of Emiliania huxleyi in mesocosm experiment; effects of nutrient supply in different N:P ratios, Sarsia, 79, 333-348.

Engel, A., U. Thoms, U. Riebesell, E. Rochelle-Newall, and I. Zondervan (2004a), Polysaccharide aggregation as a potential sink of marine dissolved organic carbon, Nature, 428, 929-932.

Engel, A., B. Delille, S. Jacquet, U. Riebesell, E. Rochelle-Newall, A. Terbrüggen, and I. Zondervan (2004b), Transparent exopolymer particles and dissolved organic carbon production by Emiliania huxleyi exposed to different $\mathrm{CO}_{2}$ concentrations: A mesocosm experiment. Aqua. Microb. Ecol., 34, 93-104.

Fabry, V. J., B. A. Seibel, R. A. Feely, and J. C. Orr (2008), Impacts of ocean acidification on marine fauna and ecosystem processes, J. Mar. Sc., 65, 414-432.
Fernández, E., P. W. Boyd, P. M. Holligan, and D. S. Harbour (1993), Production of organic and inorganic carbon within a large-scale coccolithophore bloom in the northeast Atlantic Ocean, Mar. Ecol.-Prog. Ser., 97, 271-285.

Fernández, E., J. J. Fritz, and W. M. Balch (1996), Chemical composition of the coccolithophorid Emiliania huxleyi under light-limited steady state growth, Journal of Experimental Biology and Ecology, 207, $149-160$.

Frankignoulle, M. (1994), A complete set of buffer factors for acid/base $\mathrm{CO}_{2}$ system in seawater, J. Marine Syst., 5(2): 111-118.

Frankignoulle, M., and A. V. Borges (2001), European continental shelf as a significant sink for atmospheric carbon dioxide, Global Biogeochem. Cycles, 15(3), 569-576, doi:10.1029/2000GB001307.

Frankignoulle, M., A. Borges, and R. Biondo (2001) A new design of equilibrator to monitor carbon dioxide in highly dynamic and turbid environments. Wat. Res., 35, 1344-1347.

Garcia-Soto, C., E. Fernández, R. D. Pingree, and D. S. Harbour (1995), Evolution and structure of a shelf coccolithophore bloom in the Western English Channel, J. Plankton Res., 17, 2011-2036.

Gehlen, M., R. Gangstø, B. Schneider, L. Bopp, O. Aumont, and C. Ethe (2007), The fate of pelagic $\mathrm{CaCO}_{3}$ production in a high $\mathrm{CO}_{2}$ ocean: A model study, Biogeosciences, 4, 505-519.

Godoi, R. H. M., K. Aerts, J. Harlay, R. Kaegi, Chul-Un Ro, L. Chou, and R. Van Grieke (2009), Organic surface coating on Coccolithophores Emiliania huxleyi: Its determination and implication in the marine carbon cycle, Microchem. J., 91, 266-271.

Gran, G. (1952), Determination of the equivalence point in potentiometric titrations of seawater with hydrochloric acid, Oceanol. Acta, 5, 209-218. Grasshoff, K., M. Ehrhardt, and K. Kremling (1983), Methods of seawater analysis, 2nd ed., Verlag Chemie, Weinheim, Germany.

Harlay, J., C. De Bodt, A. Engel, S. Jansen, Q. d'Hoop, J. Piontek, N. Van Oostende, S. Groom, K. Sabbe, and L. Chou (2009), In-situ abundance and size distribution of transparent exopolymer particles (TEP) in a coccolithophorid bloom in the northern Bay of Biscay (June 2006), Deep-Sea Res. I, 56: 1251-1265.

Harlay, J., et al. (2010), Biogeochemical study of a coccolithophorid bloom in the northern Bay of Biscay (NE Atlantic Ocean) in June 2004, Prog. Oceanogr., 80, 317-336, doi:10.1016/j.pocean.2010.04.029.

Heinze, C., A. Hupe, and E. Maier-Reimer (2003), Sensitivity of the marine biospheric Si cycle for biogeochemical parameter variations, Global Biogeochem. Cycles, 17(3), 1086, doi:10.1029/2002GB001943.

Ho, D. T., C. S. Law, M. J. Smith, P. Schlosser, M. Harvey, and P. Hill (2006), Measurements of air-sea gas exchange at high wind speeds in the Southern Ocean: Implications for global parameterizations? Geophys. Res. Lett., 33, L16611, doi:10.1029/2006GL026817.

Hofmann, M., and H.-J. Schellnhuber (2009), Oceanic acidification affects marine carbon pump and triggers extended marine oxygen holes, Proc. Natl. Acad. Sci. USA, 106(9), 3017-3022.

Holligan, P. M., M. Viollier, D. S. Harbour, P. Camus, and M. ChampagnePhilippe (1983), Satellite and ship studies of coccolithophore production along a continental shelf edge, Nature, 304, 339-342.

Holligan, P. M., et al. (1993), A biogeochemical study of the coccolithophore, Emiliania huxleyi, in the North Atlantic, Global Biogeochem. Cycles, 7(4), 879-900, doi:10.1029/93GB01731.

Huthnance, J. M., H. Coelho, C. R. Griffiths, P. J. Knight, A. P. Rees, B. Sinha, A. Vangriesheim, M. White, and P. G. Chatwin (2001), Physical structures, advection and mixing in the region of Goban spur, Deep Sea Res. II, 48, 2979-3021.

Jin, X., N. Gruber, J. P. Dunne, J. L. Sarmiento, and R. A. Armstrong (2006), Diagnosing the contribution of phytoplankton functional group to the production and export of particulate organic carbon, $\mathrm{CaCO}_{3}$, and opal from global nutrient and alkalinity distributions, Global Biogeochem. Cycles, 20, GB2015, doi:10.1029/2005GB002532.

Kelly-Gerreyn, B. A., D. J. Hydes, A. M. Jegou, P. Lazure, L. J. Fernand, I. Puillat, and C. Garcia-Soto (2006), Low salinity intrusions in the western English Channel, Cont. Shelf Res., 26, 1241-1257.

Klaas, C., and D. E. Archer, (2002), Association of sinking organic matter with various types of mineral ballast in the deep sea: Implications for the rain ratio, Global Biogeochem. Cycles, 16(4), 1116, doi:10.1029/ $2001 \mathrm{~GB} 001765$.

Kleypas, J. A., R. A. Feely, V. J. Fabry, C. Langdon, C. L. Sabine, and L. L. Robbins (2006), Impacts of ocean acidification on coral reefs and other marine calcifiers: A Guide for future research, report of a workshop held 18-20 April 2005, St. Petersburg, FL, sponsored by NSF, NOAA, and the U.S. Geological Survey. 
Knap, A. H., A. E. Michaels, A. Close, H. W. Ducklow, and A. G. Dickson (1996), Protocols for the Joint Global Ocean Flux Study (JGOFS) core measurements. [19]. Bergen, Norway, UNESCO. JGOFS Report.

Lee, K.-S. (2001), Global net community production estimated from the annual cycle of surface water total dissolved inorganic carbon, Limnol. Oceanogr., 46, 1287-1297.

Lessard, E. J., A. Merico, and T. Tyrrell (2005), Nitrate:phosphate ratios and Emiliania huxleyi blooms, Limnol. Oceanogr., 50, 1020-1024.

Marañon, E., and N. González (1997), Primary production, calcification and macromolecular synthesis in a bloom of the coccolithophore Emiliania huxleyi in the North Sea, Mar. Ecol. -Prog. Ser., 157, 61-77.

Margalef, R. (1997), Our biosphere. Ecology Institute, Oldendorf/Luhe, Germany.

McNeil, B. I., and R. J. Matear (2007), Climate change feedbacks on future oceanic acidification, Tellus B, 59, 191-198.

Mehrbach, C., C. H. Culberson, J. E. Hawley, and R. M. Pytkowicz (1973), Measurement of the apparent dissociation constants of carbonic acid in seawater at atmospheric pressure, Limnol. Oceanogr., 18, 897-907.

Millero, F. J., K. Lee, and M. P. Roche (1998), Distribution of alkalinity in the surface waters of the major oceans, Mar. Chem., 60(1-2), 111-130.

Milliman, J. D., P. J. Troy, W. M. Balch, A. K. Adams, Y. H. Li, and F. T. Mackenzie (1999), Biologically mediated dissolution of calcium carbonate above the chemical lysocline? Deep Sea Res. I, 46, 1653-1669.

Moore, J. K., S. C. Doney, and K. Lindsay (2004), Upper ocean ecosystem dynamics and iron cycling in a global three-dimensional model, Global Biogeochem. Cycles, 18, GB4028, doi:10.1029/2004GB002220.

Mucci, A. (1983), The solubility of calcite and aragonite in seawater at various salinities, temperatures, and one atmosphere total pressure, Am. J. Sc., 283, 781-799.

Murata, A., and T. Takizawa (2002), Impact of coccolithophorid bloom on the $\mathrm{CO}_{2}$ system in surface waters of the eastern Bering Sea shelf, Geophys. Res. Lett., 29(11), 1547, doi:10.1029/2001GL013906.

Murnane, R. J., J. L. Sarmiento, and C. Le Quéré (1999), Spatial distribution of air-sea $\mathrm{CO}_{2}$ fluxes and the interhemispheric transport of carbon by the oceans, Global Biogeochem. Cycles, 13(2), 287-305, doi:10.1029/ 1998GB900009.

Nanninga, H. J., and T. Tyrrell (1996), Importance of light for the formation of algal blooms by Emiliania huxleyi, Mar. Ecol.-Prog. Ser., 136, 195-203.

Orr, J. C., et al. (2005), Anthropogenic ocean acidification over the twentyfirst century and its impact on calcifying organisms, Nature, 437, 681686.

Paasche, E. (2002), A review of the coccolithophorid Emiliania huxleyi (Prymnesiophyceae), with particular reference to growth, coccolith formation, and calcification-photosynthesis interactions, Phycology, 40, 503-529.

Paasche, E., and S. Brubak (1994), Enhanced calcification in the coccolithophorid Emiliania huxleyi (Haptophyceae) under phosphorus limitation, Phycologia, 33(5), 324-330.

Padin, X. A., G. Navarro, M. Gilcoto, A. F. Rios, F. F. Pérez (2009), Estimation of air-sea $\mathrm{CO}_{2}$ fluxes in the Bay of Biscay based on empirical relationships and remotely sensed observations, J. Marine Syst., 75 , 280-289.

Palenik, B., and S. E. Henson (1997), The use of amides and other organic nitrogen sources by the phytoplankton Emiliania huxleyi, Limnol. Oceanogr., 42, 1544-1551.

Pingree, R. D. (1993), Flow of surface waters to the west of the British Isles and in the Bay of Biscay, Deep-Sea Res. II, 40, 369-388.

Pingree, R. D., and B. Le Cann (1989) Celtic and Armorican shelf and slope residual currents, Prog. Oceanogr., 23, 303-338.

Pingree, R. D., and A. L. New (1995), Structure, seasonal development and sunglint spatial coherence of the internal tide on the Celtic and Armorican shelves and in the Bay of Biscay, Deep-Sea Res. I, 42(2), 245-284.
Pingree, R. D., B. Sinha, and C. R. Griffiths (1999), Seasonality of the European slope current (Goban Spur) and ocean margin exchange, Cont. Shelf Res., 19, 929-975.

Raven, J., K. Caldeira, H. Elderfield, O. Hoegh-Guldberg, P. Liss, U. Riebesell, J. Shepherd, C. Turley, and A. Watson (2005), Ocean acidification due to increasing atmospheric carbon dioxide, The Royal Society, London, UK.

Rees, A. P., E. M. Woodward, C. Robinson, D. G. Cummings, G. A. Tarran, and I. Joint (2002), Size-fractionated nitrogen uptake and carbon fixation during a developing coccolithophore bloom in the North Sea during June 1999, Deep Sea Res. II, 49, 2905-2927.

Ridgwell, A., I. Zondervan, J. C. Hargreaves, J. Bijma, and T. M. Lenton (2007), Assessing the potential long-term increase of oceanic fossil fue $\mathrm{CO} 2$ uptake due to $\mathrm{CO} 2$-calcification feedback, Biogeosciences, 4 , 481-492.

Riebesell, U., I. Zondervan, B. Rost, P. D. Tortell, R. Zeebe, and F. M. M. Morel (2000), Reduced calcification of marine plankton in response to increased atmospheric $\mathrm{CO}_{2}$, Nature, 407, 364-367.

Riebesell, U., et al. (2007), Enhanced biological carbon consumption in a high $\mathrm{CO}_{2}$ Ocean, Nature, 450, 545-548

Riegman, R., W. Stolte, A. A. M. Noordeloos, and D. Slezak (2000), Nutrient uptake and alkaline phosphatase (EC 3:1:3:1) activity of Emiliania huxleyi (prymnesiophyceae) during growth under $\mathrm{N}$ and $\mathrm{P}$ limitation in continuous cultures, J. Phycol., 36, 87-96.

Robertson, J. E., C. Robinson, D. R. Turner, P. Holligan, A. J. Watson, P. Boyd, E. Fernandez, and M. Finch (1994), The impact of a coccolithophore bloom on oceanic carbon uptake in the northeast Atlantic during summer 1991, Deep Sea Res. I, 41(2), 297-341.

Sabine, C. L., et al. (2004), The oceanic sink for anthropogenic $\mathrm{CO}_{2}$, Science, 305, 367-371.

Smith, S. V., and G. S. Key (1975), Carbon dioxide and metabolism in marine environments, Limnol. Oceanogr., 20, 493-495.

Takahashi, T., J. Olafsson, J. Goddard, D. W. Chipman, and S. C. Sutherland (1993), Seasonal variation of $\mathrm{CO}_{2}$ and nutrients in the high-latitude surface oceans: A comparative study, Global Biogeochem. Cycles, 7(4), 843-878, doi:10.1029/93GB02263.

Toggweiller, J. (1993), Carbon overconsumption, Nature, 363, 210-211.

van der Wal, P., R. S. Kempers, and M. J. W. Veldhuis (1995), Production and downward flux of organic matter and calcite in a North Sea bloom of the coccolithophore Emiliania huxleyi, Mar. Ecol.-Prog. Ser., 126, $247-$ 265.

Weiss, R. F. (1974), Carbon dioxide in water and seawater: The solubility of a non-ideal gas, Mar. Chem., 2, 203-215.

Weiss, R. F., and B. A. Price (1980), Nitrous oxide solubility in water and seawater, Mar. Chem., 8, 347-359.

Wollast, R., and L. Chou (1998), Distribution and fluxes of calcium carbonate along the continental margin in the Gulf of Biscay, Aquat. Geochem., 4, 369-393.

Wollast, R., and L. Chou (2001), The carbon cycle at the ocean margin in the northern Bay of Biscay, Deep Sea Res. II, 48(14-15), 3265-3293.

Yamanaka, Y., and E. Tajika (1996), The role of the vertical fluxes of particulate organic matter and calcite in the ocean carbon cycle: Studies using an ocean biogeochemical model, Global Biogeochem. Cycles, 10(2), 361-382, doi:10.1029/96GB00634

A. V. Borges (corresponding author), B. Delille, J. Harlay, and K. Suykens, Unité d'Océanographie Chimique, Université de Liège, Allée du 6 Août, 17, B-4000 Liège, Belgium. (alberto.borges@ulg.ac.be)

C. De Bodt and L. Chou, Laboratoire d'Océanographie Chimique et Géochimie des Eaux, Université Libre de Bruxelles, Campus de la Plaine, CP 208, Blvd. du Triomphe, B-1050, Brussels, Belgium. 